\title{
Real User Costs and the Demand for Single-Family Housing
}

THE 1960s and 1970s were decades of enormous growth in the demand for single-family housing in the United States. The homeownership rate increased between 1960 and 1979 from 62 to 65 percent, and the quality of the average new home sold rose by over 25 percent. ${ }^{1}$ The increase in the homeownership rate is surprising because the numbers of young and single-person households, which historically have relatively low homeownership rates, grew much more rapidly than older, multiperson households, which have tended to have high homeownership rates. ${ }^{2}$ The increase in quality is surprising also because rising mortgage rates and relatively rapid increases in house prices doubled the real initial monthly mortgage payment on a house of constant quality. Thus it has been increasingly difficult for households to finance houses with constant quality, much less houses with higher quality. ${ }^{3}$

The author gratefully acknowledges support from the U.S. Department of Housing and Urban Development, the National Bureau of Economic Research, and the National Science Foundation. I thank Thomas Downs and James D. Shilling for research assistance and Kevin E. Villani and members of the Brookings panel for their comments.

1. Between 1963:1 and 1979:2, the average sales price of new houses actually sold rose by 275 percent, while the average sales price of a constant-quality house increased by 199 percent.

2. Dwight M. Jaffee and Kenneth T. Rosen, "Mortgage Credit Availability and Residential Construction," BPEA, 2:1979, pp. 333-76.

3. James R. Kearl, "Inflation, Mortgages and Housing," Journal of Political Economy, vol. 87 (October 1979), pp. 1115-38. 
The boom in single-family housing appears to have come to a screeching halt in late 1979 and early 1980. In just three quarters, from 1979:3 to $1980: 2$, the number of one-to-four family housing starts, at annual rates, fell by over 600,000 units; the average real price of a new house when sold declined by over 5 percent. These are the steepest declines in the postwar period, and they have come despite the introduction of moneymarket certificates at thrift institutions, the integration of the mortgage market with capital markets (particularly through the development of secondary mortgage-market instruments ), and the federal government's overriding of state usury ceilings, all of which should have reduced the cyclical sensitivity of housing.

The prolonged boom in single-family housing and the recent severe slump have a common explanation in the behavior of the real user cost of capital for owner-occupied housing. The gradual, but continual, decline in the real after-tax mortgage rate from about 3 percent in 1963 to -2 percent in 1978 stimulated both increased homeownership and the purchase of larger houses. ${ }^{4}$ Conversely, the unprecedented speed and magnitude of the rise in mortgage rates in late 1979 and 1980 pushed real after-tax mortgage rates back into the positive range and triggered the recent housing slump. For once it can truly be said that the housing recession was caused by monetary policy, rather than by a booming economy that disrupted a fragile housing finance system.

This paper begins with a discussion of how some major determinants of housing activity affect the decision of whether to own or rent and the quality of housing demanded by a homeowner. I then investigate how these determinants have changed during the past two decades. Next, equations are estimated to explain the level of homeownership, the number of oneto-four family housing starts, and the real value (a measure of quality) of these starts. Finally, some simulation experiments are conducted to forecast the real value of housing starts in 1979 and 1980 and to illustrate both the impact of rising inflation (in conjunction with the favored tax treatment of owner-occupied housing) on the real stock of single-family

4. Patric H. Hendershott and Sheng Cheng $\mathrm{Hu}$, "Inflation and Extraordinary Returns on Owner-Occupied Housing: Some Implications for Capital Allocation and Productivity Growth," Journal of Macroeconomics (forthcoming); and Kevin E. Villani, "The Tax Subsidy to Housing in an Inflationary Environment: Implications for After-Tax Housing Costs," in C. F. Sirmans, ed., Research in Real Estate (JAI Press, forthcoming in 1981). The real after-tax mortgage rate is $(1-\tau) i-p$, where the tax rate, $\tau$, is set at 30 percent; $i$ is the mortgage rate; and $p$ is the expected inflation rate calculated by Hendershott and Hu in "Inflation and Extraordinary Returns." 
housing and the effect of various financial variables on single-family housing cycles since 1960 .

\section{Determinants of the Real Value of Single-Family Housing Starts}

The real value of single-family housing starts (the dollar value of starts divided by the residential construction deflator) is the product of the number of starts and the real value of the average quality per start (which depends on the number of square feet and amenities such as fireplaces). The number of starts reflects the response of builders to demand by households and economic conditions, with household demand reflected in changes in homeownership. The real value of single-family housing starts, then, depends on four decisions. Household formation, the tenure choice (the decision of whether to own or rent), and the response of builders to that choice all affect the number of starts. The fourth decision is the perunit demand for real housing.

Of these decisions, household formation is taken as predetermined. The other three decisions are usually thought to be related to a combination of three sets of variables: demographic characteristics, real income and relative prices, and credit-market conditions. The theoretical impact of each of these sets on the three decisions is considered in turn. No attempt is made to distinguish between long-run and short-run determinants in this introductory discussion.

\section{DEMOGRAPHIC VARIABLES}

As Dwight Jaffee and Kenneth Rosen have emphasized, households with different demographic characteristics have sharply different homeownership rates. ${ }^{5}$ For example, in 1970 only one-quarter of households with a head under age twenty-five owned a home, while over one-half with a head between ages twenty-five and thirty-four arid three-quarters of those with even older heads did. Also, households made up of single individuals, especially younger ones, had far lower ownership rates than families with heads in the same age group. ${ }^{6}$ Thus the homeownership rate for

5. Jaffee and Rosen, "Mortgage Credit Availability," pp. 342-43.

6. Results from a recent microeconomic study suggest that homeownership rates also vary significantly by sex and race. See Harvey S. Rosen, "Housing Decisions and the U.S. Income Tax: An Econometric Analysis," Journal of Public Economics, vol. 11 (February 1979), p. 15. 
the entire economy will vary with changes in the demographic characteristics of the population, as well as with changes in economic variables. It therefore would appear to be useful to isolate the impact of demographic variables before attempting to identify the effects of economic variables on housing. ${ }^{7}$ Following Jaffee and Rosen, I accomplish this by expressing the ratio of homeowners, $\mathrm{HO}$, to total households, $\mathrm{HH}$, as the product of two ratios:

$$
\frac{H O}{H H}=\frac{H O}{H O A} \cdot \frac{H O A}{H H},
$$

where $H O A$ is a demographic adjusted level of homeowners. By construction, $H O A / H H$ varies with changes in the proportions of households in different demographic classes, but not with changes in the ownership rates of households in each of these classes. In contrast, the adjusted homeownership rate, $\mathrm{HO} / \mathrm{HOA}$, depends heavily on changes in homeownership rates within demographic classes and only slightly on shifts in households between classes. ${ }^{8}$ Thus the adjusted ownership rate is the variable that will be related empirically to economic determinants of the tenure choice. This ratio rose almost monotonically from 0.946 in $1960: 3$ to 1.084 in 1978:4; the adjusted and actual homeownership rates were equal in 1970.

Demographic variables could also affect the quantity of housing demanded per homeowner unit. In his microeconomic study, Harvey Rosen found that demand is independent of household size but is an increasing function of the age of the household head. ${ }^{9}$ I suspect that this variable has captured the declining impact of financial constraints on families with older household heads who have already experienced equity gains on pre-

7. This is somewhat misleading because demographic variables may simply be proxies for economic variables. To illustrate, the main reason homeownership rates are lower for young families is their greater mobility. Because of their expectations of shorter holding periods, transactions costs play a greater role in the economic decision and thus their user cost of capital is higher.

8. More specifically,

$$
H O A_{t}=H H_{t} \sum_{i=1}^{8} o_{i} h_{i t}
$$

where $h_{i t}$ is the proportion of total households of class $i$ in period $t$, and $o_{\imath}$ is the homeownership rate for class $i$ in a given base period. Thus $H O A / H H$ is independent of changes in the $o_{i}$ over time. However, there still remains a slight dependence of the adjusted homeownership rate on demographic characteristics:

$$
\frac{H O}{H O A}=\frac{\Sigma o_{i t} h_{i t}}{\Sigma o_{i} h_{2 t}} .
$$

9. Rosen, "Housing Decisions." He also finds demand to be greater for households headed by females, other things being equal, ibid., pp. 14-15. 
viously owned houses, and I account for this relation below. No demographic variables appear in the demand equations.

\section{INCOME AND PRICES}

There are two relative price variables. The tenure choice decision should depend on the rental price of housing services generated by an owner-occupied dwelling compared with the price of those services in the rental market. The real value of housing demanded by a typical owner should depend on the rental price of housing services relative to the price of nonhousing goods. The latter price is reasonably defined as the consumer price index net of the shelter component.

Specification of the rental price series is a difficult task. For owneroccupied housing, the rental price under quite simplifying assumptions is the product of a real after-tax interest rate (plus some other, largely timeinvariant, costs) and the price of a constant-quality house. ${ }^{10}$ Measurement of the expected inflation and financing rates for the expected holding period is required, and the rental price obviously varies among households depending on their tax brackets. I refer to this measure of rental price as user cost. Figure 1 shows time series data for real user costs (user costs deflated by the price of nonhousing goods) for the period from 1956:1 to 1979:4 for owner-occupied households in the 15 percent and 30 percent tax brackets (the lowest two series). ${ }^{11}$ Both real user costs for owner-occupied housing rise in the second half of the 1950s, reach a plateau in the early 1960s, and then show a downward trend through early 1979 because of a decline in the real after-tax mortgage rate. ${ }^{12}$

10. The homeownership component of the consumer price index, which is related to a nominal before-tax interest rate, has been negatively correlated with this rental price over the 1965-80 period. See Ann J. Dougherty and Robert Van Order, "Inflation and Housing Cost," working paper (Department of Housing and Urban Development, Office of Economic Affairs, May 1980).

11. The precise construction of the series is described in Hendershott and $\mathrm{Hu}$, "Inflation and Extraordinary Returns"; and Patric H. Hendershott and James D. Shilling, "The Economics of Tenure Choice, 1955-79," in C. F. Sirmans, ed., Research in Real Estate (JAI Press, forthcoming in 1981).

12. The user costs are lower in 1964 for those in higher tax brackets because of greater tax savings on their property taxes and interest payments; the decline since then is greater because their tax saving on interest payments is larger. The real user cost for those in the 45 percent tax bracket was, in fact, roughly zero in late 1978 and early 1979, which implies that optimal behavior of these households consisted of owning marginal unused rooms. For a discussion of this phenomenon and its macroeconomic implications, see Hendershott and $\mathrm{Hu}$, "Inflation and Extraordinary Returns." 


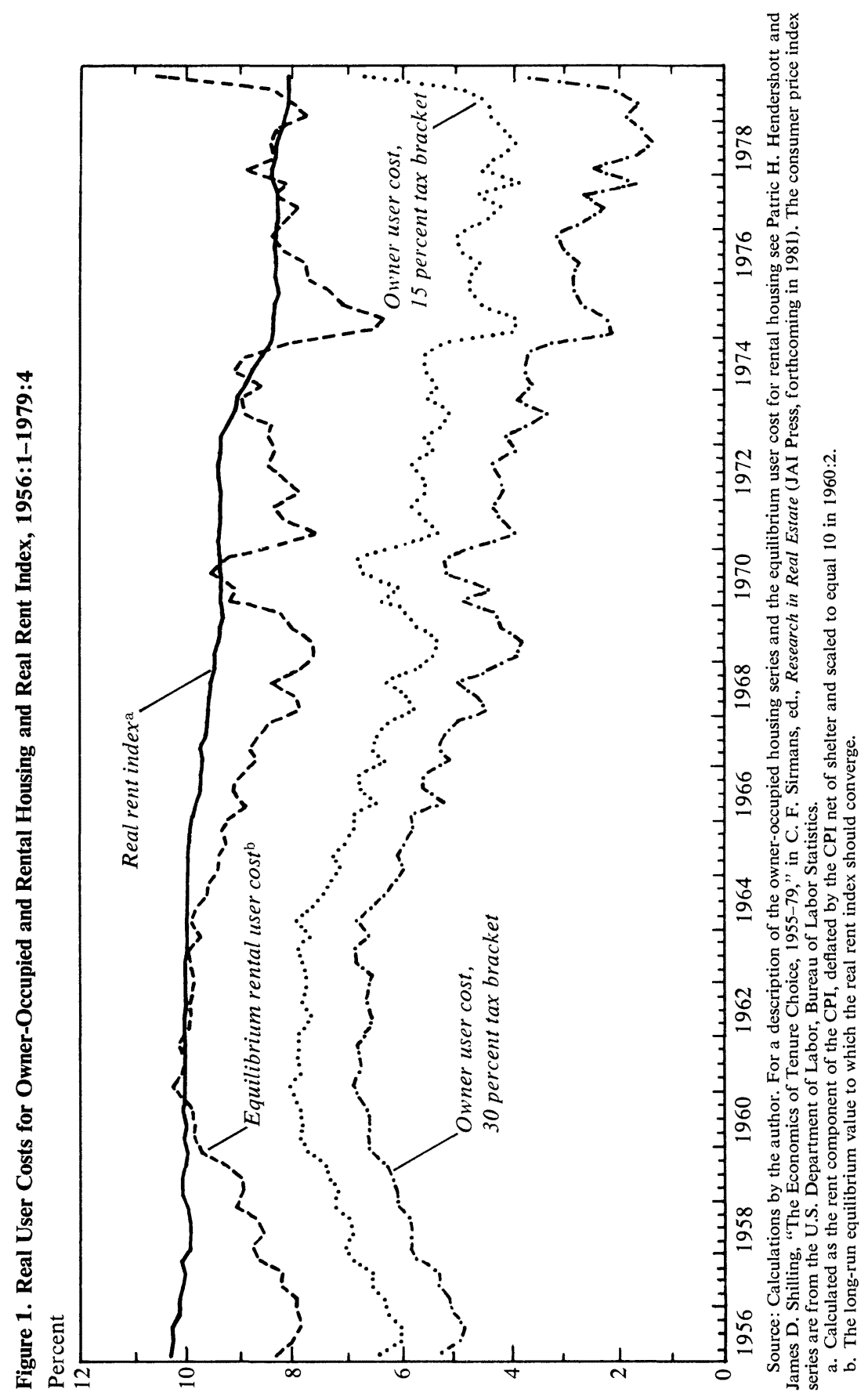


Specification of the rental price series for rental housing is at least as difficult. Investigators generally use an observed market rent index such as the CPI rent component. ${ }^{13}$ The real rent index (using the CPI net of shelter as a deflator and scaled to equal 10 percent in 1960:2) is the smooth series plotted in the figure. As an alternative, an equilibrium user cost for rental housing is calculated. In the long-run equilibrium, the observed rent index should converge to this value. There are two advantages of using the ratio of the equilibrium user cost for owner-occupied housing to the user cost for rental housing in equations explaining tenure choice. First, these series are comparable conceptually. (Because no rents are observed for owner-occupied housing, it is not possible to compare market rents for owner-occupied and rental housing.) Second, errors in the measurement of expected inflation and financing rates tend to cancel out. As can be seen in figure 2, the ratio of the user cost for owner-occupied housing to the rental user cost is a smoother series than the ratio of the former to the market index.

In contrast to the user costs for owner-occupied housing, the real user cost for rental housing (figure 1) shows no discernible trend over the past twenty-five years, although there is a slight bulge in the early 1960s. The failure of this cost to decline sharply between 1964 and late 1978 in the face of an estimated 5 percentage point fall in the real after-tax mortgage rate (for landlords in the 50 percent tax bracket) occurred because of two factors: the tax reform legislation of 1969 and 1976 and the acceleration of inflation. The reform legislation created a minimum tax on accelerated depreciation and capital gains, increased the proportion of accelerated depreciation subject to recapture, and lengthened the minimum interval over which the interest and property taxes incurred during the construction period can be amortized; inflation eroded the real value of tax depreciation, which is based on historical cost. Thus the ratio of the real user cost for owner-occupied housing to that for rental housing has fallen. For households in the 15 percent tax bracket the ratio shown in figure 2 declines from 0.8 in 1959 to 0.5 in 1978; for the 30 percent bracket, the decline is from 0.7 to 0.2 . This general decrease in the relative cost of homeownership is broadly consistent with the observed rise in the adjusted homeownership rate.

13. For example, see Harvey S. Rosen and Kenneth T. Rosen, "Federal Taxes and Homeownership: Evidence from Time Series," Journal of Political Economy, vol. 88 (February 1980), pp. 59-75. 


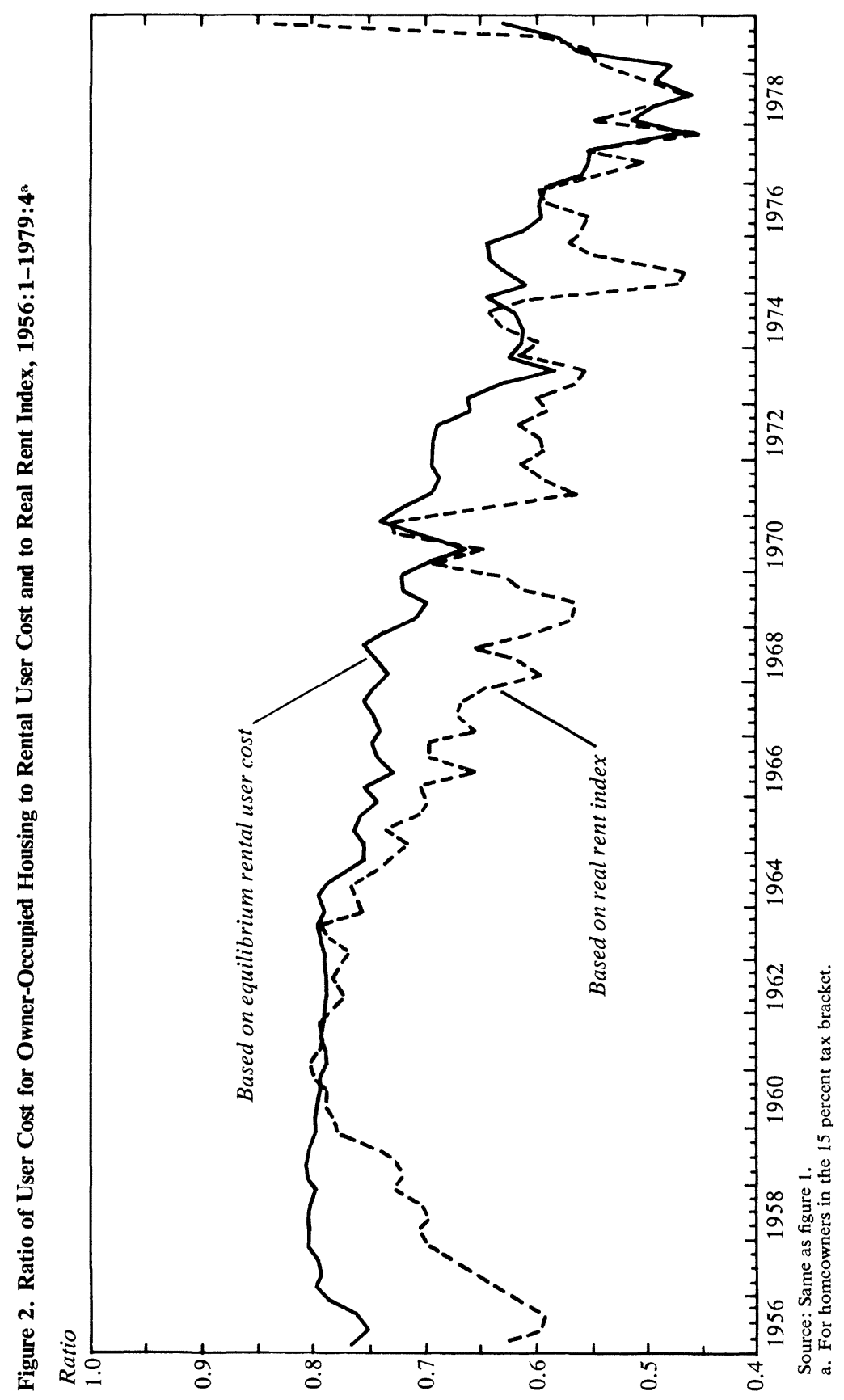


The size and quality of the housing demanded by a homeowner is assumed to be related to the permanent real disposable income of that owner. The proxy for this variable is an average of recent values of real disposable income per household. This variable (four-quarter average) rose from $\$ 9,000$ (1972 prices) in 1960 to more than $\$ 12,000$ in 1978 . Rosen finds that income also affects the tenure choice because households with higher income are more likely to own. ${ }^{14} \mathrm{He}$ attributes this to any of three hypotheses: ownership per se is a superior good; risk aversion declines with income; or financial constraints decline with income. The rise in income during the 1960-78 period is consistent with the increase in the adjusted homeownership rate, and its significance is tested below.

\section{VARIABLES MEASURING CREDIT-MARKET CONDITIONS}

If interest rates rise one-for-one with increases in expected inflation, such increases raise the demand for housing per owner-occupied unit. This is because mortgage interest is tax deductible and interest income from financial assets, the usual alternative to own equity investment in houses, is taxable-in other words, the financing cost and rate of expected capital appreciation rise equally, but the latter is not taxed while the former is deductible. This effect is captured by the real user cost variable described above.

James Kearl, following William Poole, argues that this is not the end of the story because the increased financing cost impinges on the buyer immediately while the appreciation gain occurs in the future. ${ }^{15}$ If lenders are unwilling to make funds available on the basis of these future expected gains and households cannot either (1) meet the higher mortgage payments by borrowing in other forms or by rechanneling their savings to housing equity from other assets, or (2) reduce the payments by reallocating more wealth to housing at the time of purchase, the quantity of housing demanded by such households will be reduced. That is, increases in expected inflation will not stimulate the real value of the average housing start as much as the user-cost analysis suggests; in fact, increased inflation could even reduce demand.

14. Rosen, "Housing Decisions," pp. 13-14.

15. Kearl, "Inflation, Mortgages and Housing"; and William Poole, "Housing Finance under Inflationary Conditions," in Ways to Moderate Fluctuations in Housing Construction, Federal Reserve Staff Study (Board of Governors of the Federal Reserve System, 1972), pp. 355-76. 


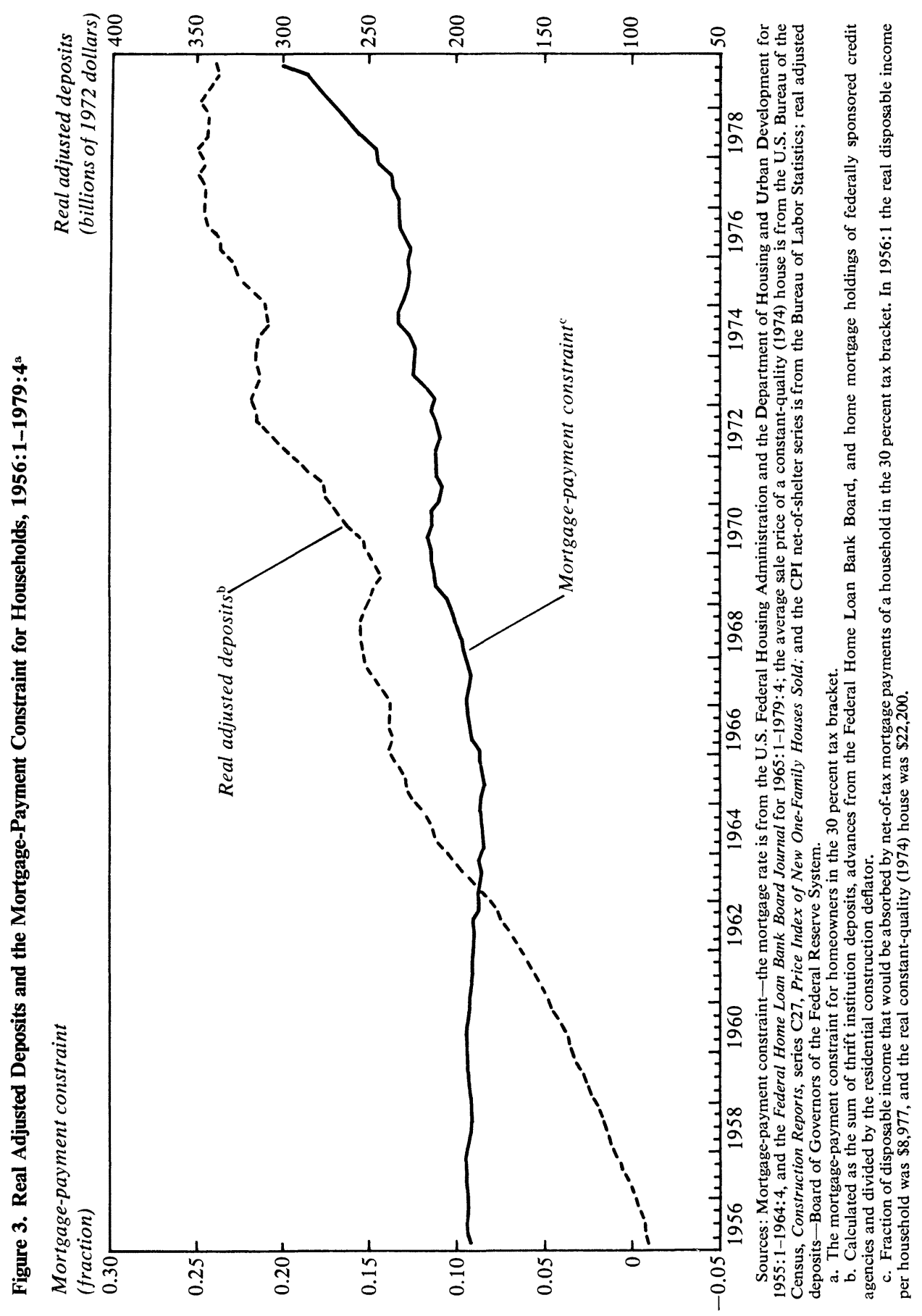


A variable that should capture the impact of this mortgage-payment constraint is the ratio of net-of-tax mortgage payments on the desired real value of a house to disposable income per household, assuming 75 percent financing at the current mortgage rate. But the desired real value of a house in the absence of this constraint is unknown. I assume that the desired real value of a house would have risen proportionately with the rise in real disposable income per household. The mortgage-payment constraint is then based on the real cost of a constant-quality house, taken to be the average new home constructed in 1974 , deflated by real disposable income per household-all in 1956:1 prices. The fraction of disposable income that would be absorbed by net-of-tax mortgage payments of a household in the 30 percent tax bracket is shown in figure 3 . A number of characteristics of this series are of interest. First, the fraction was only marginally higher in the $1969-72$ period-0.110 - than the approximately 0.095 that existed in 1960 . Second, the fraction periodically increased by 25 to 30 percent during periods of normal (roughly 2 percentage points) increases in the mortgage rate (1966-69, 1971-74, 1977-78). Third, the fraction rose by an extraordinary amount in 1979 and early 1980 . The current fraction, based on a 13 percent mortgage rate $(0.21)$, is nearly double the 1971 level. ${ }^{16}$

The availability of funds at the traditional mortgage financing institutions and mortgage support by the federally sponsored credit agencies also are seen by many to be an important determinant of housing production, although there is much controversy regarding this issue. Jaffee and Rosen are probably the best-known advocates of the role of availability and have reported empirical results of an incredibly large impact. ${ }^{17}$ However, the most extreme position on availability is that incorporated in the recent specification of the housing sector in the Federal Reserve Board model, in which starts are determined solely by a credit-availability vari-

16. This is a slight overstatement because of the tendency for people with constant real incomes to be in increasingly higher tax brackets during the past fifteen years.

17. Jaffee and Rosen in "Mortgage Credit Availability" report that $\$ 1$ billion increase in annual deposit inflows increases single-family housing starts by 15,000 units (p. 351) and multifamily starts by 16,000 units (p. 353). At average prices of $\$ 60,000$ (p. 351, note 16 ) and $\$ 50,000$ (my estimate), the value of starts would rise by $\$ 1.7$ billion. Given that thrift institutions use most of their funds to finance existing house transactions at current prices, this estimate seems at least four times too high even for those who believe in the impact of mortgage availability. See the discussion of equations 3-2 through 3-5 below. 
able in the 1960:1-1960:3,1966:3-1967:1, 1969:2-1970:1, and 1973: 3-1975:1 periods. ${ }^{18}$ On the other hand, Paul de Rosa, and Allan Meltzer earlier, could find no impact of credit availability. ${ }^{19}$ Although much disagreement exists about the impact of availability on the short-run housing cycle, there appears to be general agreement that credit availability has not affected the long-run housing stock, ${ }^{20}$ that is, the subsequent reintermediation of deposits induces production to replace that lost during the previous period of disintermediation.

Following Jaffee and Rosen, the credit-availability measures in this paper are based on the sum of thrift institution deposits, Federal Home Loan Bank Board advances, and home mortgage holdings of federally sponsored credit agencies. This sum-adjusted deposits (DEPA) measured in millions, deflated by the residential construction deflator-is shown in figure 3 as real adjusted deposits (DEPAR). Two measures of availability based on adjusted deposits are tested. The first is the average change in adjusted deposits in the previous two quarters, the short lag reflecting the commitment process, divided by the price of a constantquality house $(P C Q H)$ - that is, the real value of the increase in adjusted deposits. This variable, $\triangle D E P A / P C Q H$, is very close to that used by Jaffee and Rosen and is denoted by $J R A A$. It represents the number (in thousands) of constant-quality houses that could be purchased with the change in adjusted deposits. A reservation about this variable is that it suggests that housing production is always affected by availability; either a shortage of funds restricts production or a surplus of funds allows previously lost production to catch up. This variable ignores the impact of inflation on the purchasing power of the existing stock of deposits, deposits that are constantly being used to finance houses that are rolling over at higher prices.

According to the second specification, availability is assumed to be

18. The model is discussed in Neil G. Berkman, "Mortgage Finance and the Housing Cycle," New England Economic Review (September-October 1979), pp. 54-76.

19. Paul de Rosa, "Mortgage Rationing and Residential Investment: Some Results from a Brainard-Tobin Model," Journal of Money, Credit, and Banking, vol. 10 (February 1978), pp. 75-87; and Allan H. Meltzer, "Credit Availability and Economic Decisions: Some Evidence from the Mortgage and Housing Markets," Journal of Finance, vol. 29 (June 1974), pp. 763-77.

20. See Dwight M. Jaffee and Kenneth T. Rosen, "Estimates of the Effectiveness of Stabilization Policies for the Mortgage and Housing Markets," Journal of Finance, vol. 33 (June 1978), p. 933. 
restricted when the average quarterly growth rate in real adjusted deposits during the previous two quarters is less than one-quarter percent; it is assumed to remain restricted until future growth brings real adjusted deposits above the one-quarter percent trend line from the point just before the period of restriction. Subsequent growth above the trend line is assumed to induce catch-up production until the net impact on production is zero. ${ }^{21}$ Both this variable, $A A$, and the deflated average change in adjusted deposits, $J R A A$, are shown in figure 4. Although the $A A$ series oscillates around zero (always equaling zero between bouts of availability constraint), the Jaffee-Rosen variable is more like a step function. Between 1965:1 and 1970:3 the series averages 130; between 1970:4 and 1978:4 it averages 300. Moreover, all values in the latter period exceed every value in the earlier period. Thus the precise interpretation of this variable is highly uncertain.

It has been suggested that the availability measure should be expanded to account for the increased mortgage financing by nontraditional lenders. More specifically, some have advocated adding mortgage pools or Government National Mortgage Association (GNMA) pass-through securities to adjusted deposits. ${ }^{22}$ This seems inappropriate for a number of reasons. First, pools denote a type of mortgage financing instrument rather than a sector that finances residential construction; the underlying financing is provided by households and a wide variety of financial institutions. In fact, because thrift institutions hold roughly 25 percent of GNMA securities, the addition of pools to adjusted deposits would constitute significant double counting. Second, the holdings of pool securities by nonthrift institutions are actual holdings of mortgages, while adjusted thrift institution deposits are funds that could support mortgage holdings. If nonthrift pools were to be included in an availability variable, logic dictates that the variable should be all mortgage holdings or mortgages outstanding, rather than these pools plus thrift institution deposits. ${ }^{23}$ Although it is likely that a close relation between housing outlays and changes in

21. Let $A_{t}=D E P A R_{t}-(1.0025)^{t} D E P A R_{(\prime)}$, where $D E P A R_{0}$ is the value during the quarter before the restricted period. The value of $A$ is initially negative and then takes on positive values until $\Sigma A_{t}$ for a given episode equals zero. The availability variable, $A A_{t}$, equals $1 / 2\left(A_{t-1}+A_{t-2}\right)$.

22. See the comments on Jaffee and Rosen, "Mortgage Credit Availability," pp. $377-86$.

23. The recently estimated housing sector model of the Federal Reserve moves in this direction (see note 18). 


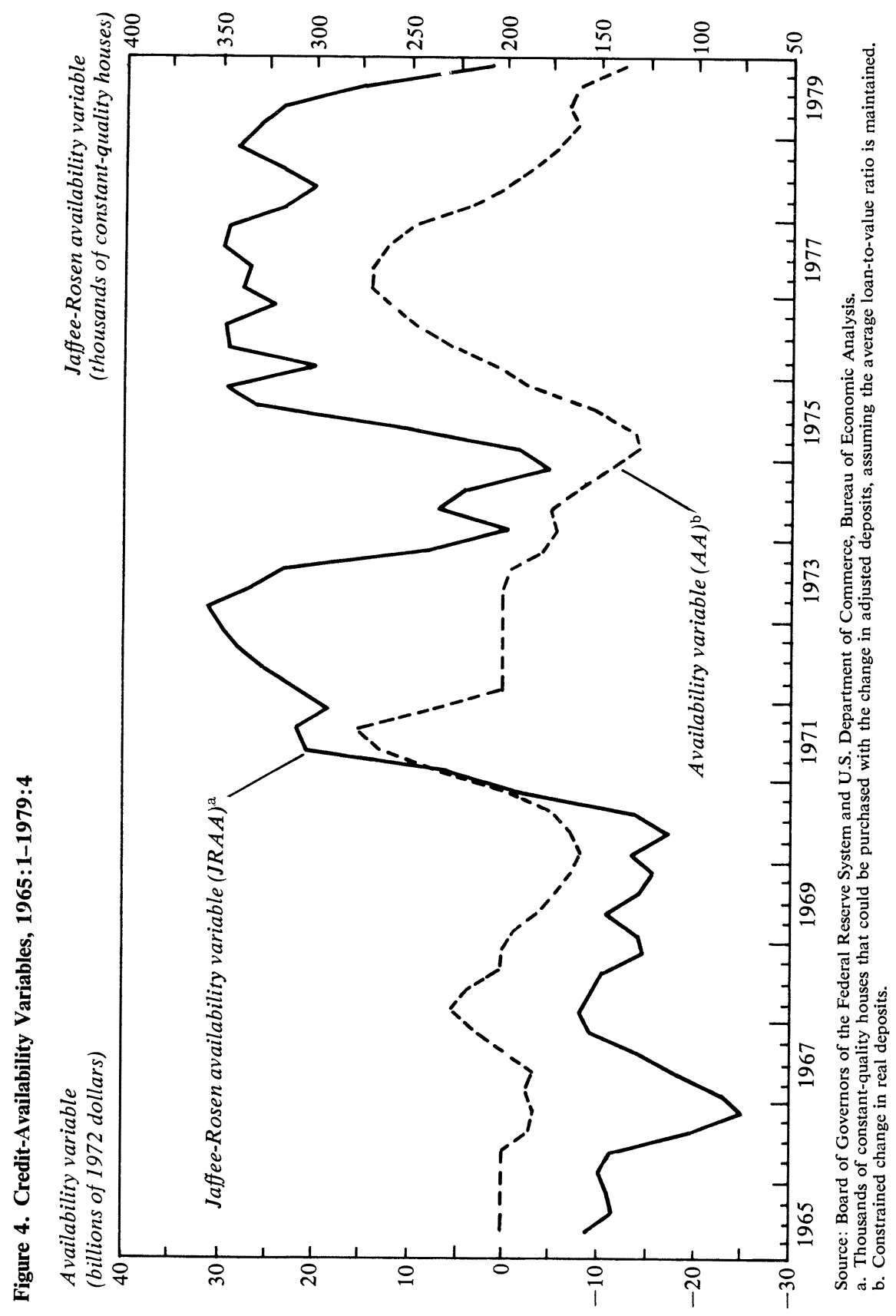


this series (total mortgage purchases or issuances) exists, it seems more likely that the outlays cause the mortgage issuances than the reverse. Inclusion of mortgage purchases or issuances in housing equations would give rise to highly spurious results. The expansion of secondary mortgage markets has integrated the mortgage market more closely with capital markets generally. ${ }^{24}$ This should reduce the impact of the rationing variables in the most recent (1979-80) cycle. In fact, if the integration is substantial, the unavailability of mortgage credit should no longer be a problem and forecasts of 1979-80 that exclude any availability effect should be more accurate.

\section{Tenure Choice $^{25}$}

The adjusted homeownership rate, $H O / H O A$, is related to the four basic determinants discussed above: the ratio of the real user cost of owner-occupied housing, $c$, to the cost of renting, $r$, measured by either the real rental user cost or the rent component of the CPI; the mortgage-payment constraint, $m$; credit availability, $A A$; and real disposable income per household, $y$ :

$$
H O / H O A=\theta\left(\frac{c}{r}, m, A A, y\right) .
$$

The expected signs of the partial derivatives are negative for $c / r$ and $m$; positive for $A A$; and unknown for $y$. The real user costs are tested for homeowners in both the 15 percent and the 30 percent tax brackets.

It is reasonable to expect long lags in the adjustment of the homeownership rate to changes in its fundamental determinants. An increase in the economic attractiveness of homeownership must be perceived by the household; a decision must be made regarding the explicit form and location of the house; and the house must be constructed (or converted from a rental unit). The first two lags might be short for some households and a small increase in the homeownership ratio could be achieved through

24. For a discussion of secondary mortgage markets and the integration of the mortgage market, see Patric H. Hendershott and Kevin E. Villani, "Secondary Mortgage Markets and the Cost of Mortgage Funds," Journal of the American Real Estate and Urban Economics Association, vol. 8 (Spring 1980), pp. 50-76.

25. This section is based in part on Hendershott and Shilling, "The Economics of Tenure Choice." 


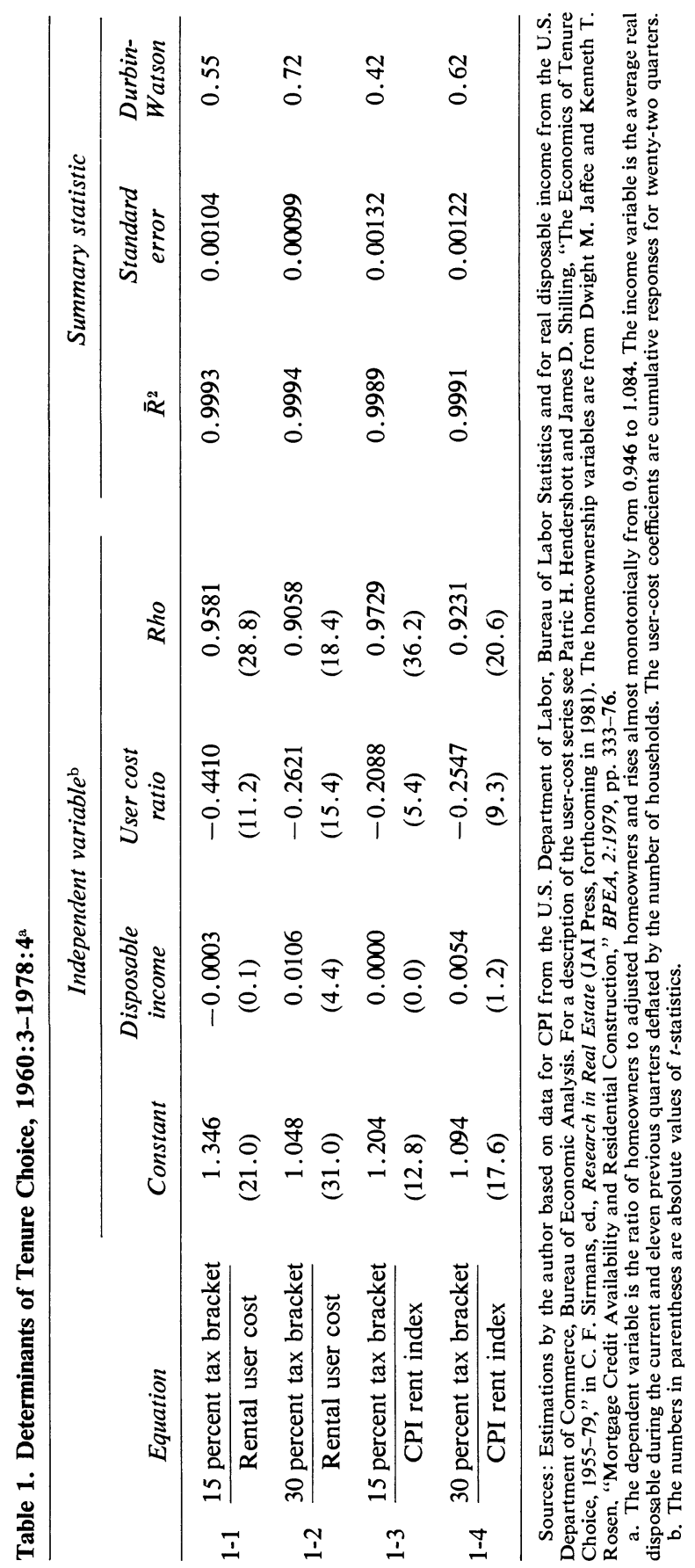


a drop in unsold or vacant existing houses, but the full response to a significant decline in the cost of homeownership undoubtedly does not occur for a number of years. Because the responses are expected to build up for a time and then taper off, a stock-adjustment model was not used. Rather, combinations of weighted averages and polynomial distributed lags were tested. The lag weights of the distribution were assumed to lie along a third-degree polynomial (with no end-point constraints), and the length of the lag was extended as long as the expected negative or positive relations held. Both linear and logarithmic forms were estimated.

The mortgage-payment constraint variable and the credit-availability variable have not had significant impacts on tenure choice. This is true regardless of the form of the equation estimated or the assumed tax bracket of the household. Estimates excluding these variables are presented in table 1 . The income variable is statistically significant in the second equation only; the user-cost variables perform as expected in all equations. ${ }^{26}$ The standard errors of the equations, including the ratios of the user costs, are about 25 percent less than those of the equations using the market rent index.

The weights on the lagged user-cost ratios in equations 1-1 through 1-4 are summarized by quarters in table 2 . Both the humped weight pattern and the nearly five-year period for complete adjustment seem plausible. The estimated response when the 30 percent tax bracket and the rental user cost are used is somewhat less rapid than that in the other formulations; 14 percent of the response occurs within two years rather than the 28 to 33 percent response in the other equations.

The magnitudes of the coefficients on the different user-cost ratios in these equations indicate large and similar effects from observed changes in the different user-cost measures. The estimated impact in equation 1-1 of the observed decline in the ratio accounts for 66 percent of the ob-

26. These equations appear to suffer from substantial autocorrelation even after the semidifference transformation, but this is deceiving. Examination of the residuals of the equations reveals a distinct annual clustering, that is, the residuals for the period from 1960:3 to 1961:2 are similar; a jump occurs in 1961:3; and the pattern is repeated. (This phenomenon follows from the construction of the data. Only annual data are available for both the number of homeowners and the adjusted homeowners; this ratio is calculated for the second quarter of the year and interpolated linearly between second quarters.) When the residuals are averaged for each of the eighteen annual clusters and computed Durbin-Watson statistics are based on these, the result is statistics greater than 2 . 
Table 2. Lagged Responses to User-Cost Ratios, 1960:3-1978:4

\begin{tabular}{|c|c|c|c|c|c|c|c|}
\hline \multirow{2}{*}{\multicolumn{2}{|c|}{ Equation }} & \multicolumn{6}{|c|}{ Number of quarters lagged ${ }^{a}$} \\
\hline & & $\begin{array}{c}\text { Zero to } \\
\text { three }\end{array}$ & $\begin{array}{c}\text { Four to } \\
\text { seven }\end{array}$ & $\begin{array}{c}\text { Eight to } \\
\text { eleven }\end{array}$ & $\begin{array}{c}\text { Twelve } \\
\text { to } \\
\text { fifteen }\end{array}$ & $\begin{array}{c}\text { Sixteen } \\
\text { to } \\
\text { nineteen }\end{array}$ & $\begin{array}{c}\text { Twenty } \\
\text { to } \\
\text { twenty- } \\
\text { two }\end{array}$ \\
\hline \multirow{2}{*}{$1-1$} & 15 percent tax bracket & 0.12 & 0.16 & 0.23 & 0.26 & 0.20 & 0.04 \\
\hline & Rental user cost & $(2.8)$ & $(4.3)$ & $(6.9)$ & $(7.5)$ & $(4.4)$ & $(1.0)$ \\
\hline \multirow{2}{*}{$1-2$} & 30 percent tax bracket & 0.05 & 0.09 & 0.20 & 0.30 & 0.28 & 0.07 \\
\hline & Rental user cost & $(1.0)$ & $(2.4)$ & $(6.8)$ & $(8.4)$ & $(6.0)$ & $(2.3)$ \\
\hline \multirow{2}{*}{$1-3$} & 15 percent tax bracket & 0.15 & 0.18 & 0.20 & 0.20 & 0.19 & 0.08 \\
\hline & CPI rent index & $(2.3)$ & $(3.3)$ & $(3.5)$ & $(4.4)$ & $(4.4)$ & $(2.3)$ \\
\hline \multirow{2}{*}{$1-4$} & 30 percent tax bracket & 0.15 & 0.16 & 0.19 & 0.21 & 0.20 & 0.09 \\
\hline & CPI rent index & $(2.8)$ & $(3.0)$ & $(5.1)$ & $(5.7)$ & $(5.2)$ & $(3.2)$ \\
\hline
\end{tabular}

Sources: Same as table 1.

a. The numbers in parentheses are absolute values of $t$-statistics.

served increase in the adjusted homeownership rate between early 1960 and the end of 1978, while the impact of the decline based on equation 1-2 explains 56 percent of the increase. If the ratio of user costs had not fallen over this period, 3.5 to 4.0 million fewer households would have been homeowners at the end of 1978 than the observed 50 million. Put another way, the homeownership rate would have been about 60 percent, rather than the observed 65 percent.

These results are roughly comparable to those of Harvey and Kenneth Rosen. ${ }^{27}$ The Rosens relate the homeownership rate annually over the 1949-74 period to the ratio of user costs, per capita real consumption (a proxy for permanent income), a credit-availability variable (the real growth rate in deposits of thrift institutions), and demographic variables (their dependent variable being the observed homeownership rate, not the adjusted rate). The greatest difference between the Rosens' results and mine is in the treatment of demographic variables. Through construction of the adjusted homeownership ratio, demographic factors in my analysis are forced to cause a reduction in the unadjusted ratio from 0.62 in 1960 to 0.58 in $1974 .{ }^{28}$ The Rosens, in contrast, find no impact for such factors.

27. Rosen and Rosen, "Federal Taxes and Homeownership."

28. Jaffee and Rosen, "Mortgage Credit Availability," p. 345. Jaffee kindly supplied me with both the $H O$ and $H O A$ series used in their analysis. 
They do find income to be a significant determinant (as I did in equation 1-2) and credit availability to be insignificant (with a $t$-statistic of 1.3). The most striking similarity in the Rosens' and my results can be seen in the user-cost ratio. They, too, find a significant, much-delayed response (with the peak adjustment occurring in the third year following a change in the user-cost ratio). To provide an indication of the magnitude of their estimated response, they compute the long-run value of the homeownership rate in 1974 on the assumption that property taxes and interest were not tax deductible. The calculated value is 0.60 compared to the observed value of $0.64 .{ }^{29} \mathrm{I}$ have attempted to perform the same experiment, which consists of recomputing the homeownership user costs without the deductions, obtaining the impact of these changes on $\mathrm{HO} / \mathrm{HOA}$ in equations 1-1 and 1-2, and transforming these changes into impacts on $\mathrm{HO} / \mathrm{HH}$, the observed homeownership rate. The results are 0.590 (the tax rate at 15 percent) and 0.575 (the tax rate at 30 percent). These calculations suggest approximately the same sensitivity of tenure choice to relative prices as that obtained by the Rosens. ${ }^{30}$

\section{Number of Housing Starts}

The data on starts and their value do not refer to houses occupied by owners but to one-to-four family units. These houses can be occupied by owners, $H O$; can be rented, $N R$; or can be vacant, $N V$. Thus the change in uses of such housing, $\Delta N$, is

$$
\Delta N=\Delta H O+\Delta N R+\Delta N V .
$$

The change in the stock of houses is the sum of completed starts, CST, and conversions from multifamily units, $C O N V$, minus removals, $R E M$ :

$$
\Delta N=C S T+C O N V-R E M .
$$

By definition, there is ex post equality between $\Delta N$ in equations 3 and 4; ex ante, equality is unlikely.

29. Rosen and Rosen, "Federal Taxes and Homeownership," p. 68.

30. When the homeownership equation was estimated in logarithmic form and this experiment was performed, the calculated value of the homeownership rate in 1974 was 0.60 for either cost of capital. 
Single-family starts are generally completed about three months (one quarter) after they are initiated. Prices of new units are assumed to be a markup on costs, and builders are assumed to set current starts, $S T$, to match expected demand. In the aggregate, combining equations 3 and 4 implies

$$
S T=C S T_{+1}=\Delta H O_{+1}^{e}+\Delta N R_{+1}^{e}+\Delta N V_{+1}^{e}-C O N V_{+1}^{e}+R E M_{+1}^{e},
$$

where the superscript denotes expected desired future changes.

The major force determining housing starts has almost certainly been the expected change in homeownership and, possibly, expected removals. Ex post conversions and changes in unsold new units have been relatively small, and changes in the number rented must have been minor. Conversions averaged 17,000 a year in the $1970-75$ period, and rose to 20,000 in $1976,45,000$ in 1977 , and 80,000 in $1978 .{ }^{31}$ The annual change in unsold new single-family houses measured at year-end exceeded 75,000 only once between 1963 and 1979. In contrast, the mean annual level of one-to-four family housing starts in the $1976-79$ period was $1,140,000$.

Three variables reflect expectations of future increases in the demand for owner-occupied housing. These are recent observed changes in homeownership, the projected average growth in homeownership during the next year because of the growth in households in the different demographic classes (the projected growth in $H O A$ ), and the expected long-run change in homeownership due to anticipated adjustments to the user-cost ratio. The first two variables are measured as the observed average change in homeownership during the current and previous three quarters, $A C H O$, and the change in adjusted homeownership during the next four quarters, $A C H O A$. The last variable, $L R U C$, is based on equation 1-1, the adjusted homeownership rate. Recall from table 1 that

$$
\frac{H O}{H O A}=\alpha_{0}-\alpha_{1} \sum w_{i}\left(\frac{c}{r}\right)_{-i},
$$

31. An additional increase to 135,000 occurred in 1979 . These are high estimates of owner-occupied houses created because an entire property is considered as converted if a single unit in a rental building or complex has been sold as a condominium and because the new owners can rent the units rather than occupy them. See Department of Housing and Urban Development, Division of Policy Studies, The Conversion of Rental Housing to Condominiums and Cooperatives: A National Study of Scope, Causes, and Impacts (U.S. Government Printing Office, 1980), pp. IV-4 through IV-5. 
where $\Sigma w_{i}=1$. The long-run expected adjusted homeownership rate, assuming that the current user-cost ratio continues in the future, is

$$
\frac{H O^{*}}{H O A}=\alpha_{0}-\alpha_{1} \frac{c}{r}
$$

Thus the long-run change in homeownership that will result from full adjustment to the current user-cost ratio is

$$
L R U C=\alpha_{1}\left[\sum w_{i}\left(\frac{c}{r}\right)_{-i}-\frac{c}{r}\right] \text { HOA }
$$

This variable is uniformly (with one minor exception) positive throughout the estimation period but turns sharply negative in late 1979 and early 1980.

Housing starts may also be affected by the availability of mortgage credit. Allowing for the possible impact of the two credit-availability variables yields the following general relation:

$$
S T=\phi(A C H O, A C H O A, L R U C, A A, J R A A),
$$

where starts are related positively to components in the $\phi$ function.

Some estimates of a linear version of equation 6 are presented in table 3..$^{32}$ Equations 3-1 and 3-2 are estimated both with and without the autocorrelation correction. In equation 3-1 the coefficients are all statistically significant with the expected sign. Moreover, the long-run impact of a change in homeownership on starts is close to one-for-one; the sum of the products of the coefficients on the three homeownership variables and their means is 272 as compared with 257 , the mean annual average change in homeownership. However, the equation exhibits significant autocorrelation. When the correction for this is made in equation 3-2, the coefficients on change in homeownership imply a response of starts to increases in homeownership that is too large. To reduce the response, the constant term was arbitrarily constrained to -50 , slightly more than the constant in 3-1. As shown in 3-3, this does not reduce the explanatory power of

32. A case easily can be made that the credit-availability variables should enter multiplicatively with the homeownership variables. However, this is complicated by the fact that some variables alternate by sign ( $L R U C$ and $A A$ ) and by difficulties in simulating disturbances with a multiplicative equation. 


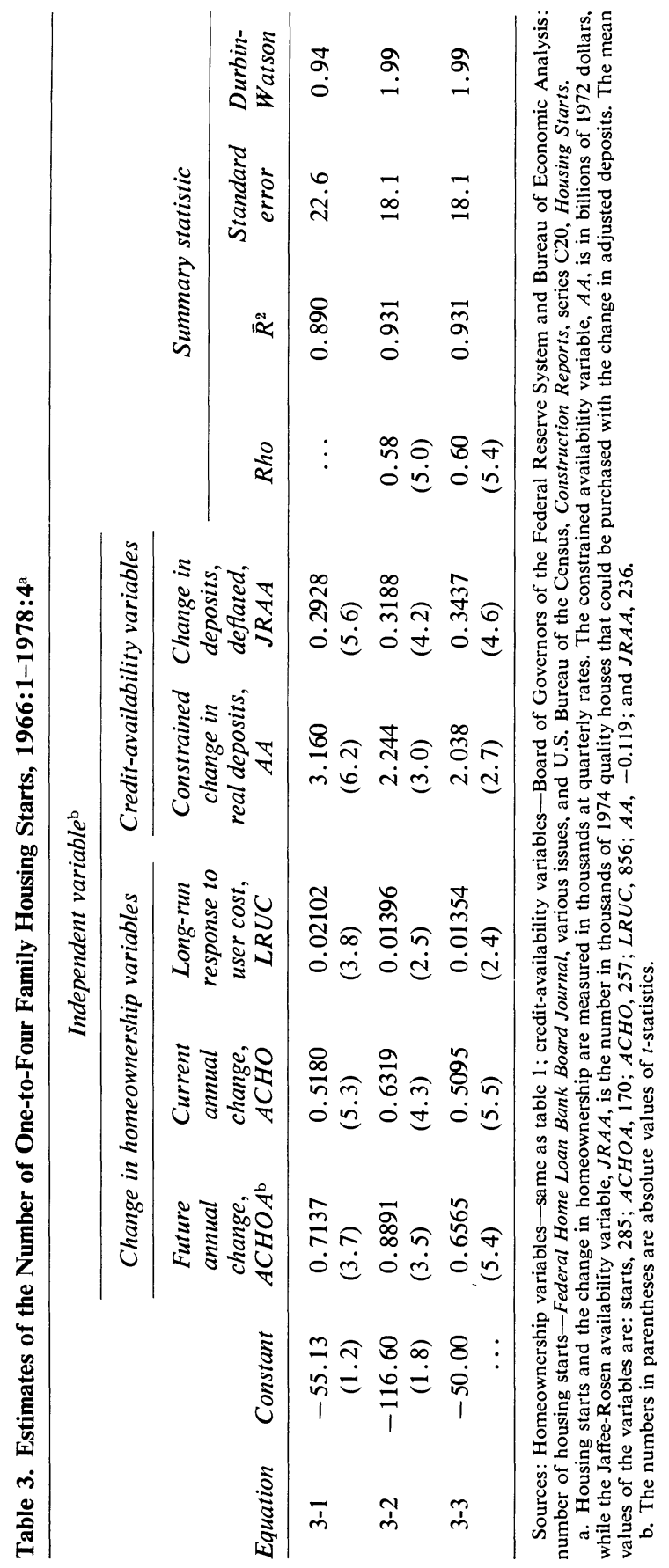


the relation, but the response of starts to changes in homeownership is lowered appropriately. (The sum of the products of the means of the three homeownership variables and their coefficients is 254.)

The coefficients on the availability variables in equation 3-3 imply that an increase in deposits of $\$ 1$ billion in 1978 would raise starts by just under 7,000 units. $^{33}$ This is only 45 percent of the impact reported by Jaffee and Rosen. Even my relatively small estimated impact on starts suggests that 31 percent of incremental funds of thrift institutions is used to finance new construction of one-to-four family houses, ${ }^{34}$ and this is implausibly large. Only 20 percent of the loans from savings and loan institutions (net of refinancings) that were closed during each of the years from 1976 to 1979 were used for this purpose, ${ }^{35}$ and the fraction was surely lower for mutual savings banks because of their large investments in commercial mortgages and corporate bonds. The results of Jaffee and Rosen suggest 68 percent financing of new single-family construction. ${ }^{36}$

One interpretation of availability coefficients that are implausibly large is that the availability variable is correlated with credit shortages at other institutions such as commercial banks. This may be the case; however, the policy implications that follow from this interpretation-and the type of policy simulations that would be appropriate-are quite different from those of a pure thrift-institution availability effect. Suppose, for example, that an availability coefficient implies that an increase of $\$ 1$ billion in thrift institution deposits raises starts by 7,000 , but that the effect is really an increase of 5,000 units due to thrift institution deposits and an increase of 2,000 units due to a simultaneous increase in deposits at commercial banks. A policy that increases thrift institution deposits by $\$ 1$ billion at the expense of bank deposits, such as creating a deposit rate differential, would increase starts by 3,000 , rather than by 7,000 .

33. $\Delta S T=0.344 / 0.06+2.038 / 1.81=6.86$, where 0.06 is the price of a constantquality house (in millions of dollars) and 1.81 is the residential construction deflator $(1972=1.0)$ in 1978 .

34. $P C Q H \triangle S T / \triangle D E P A=0.344+[(0.06)(2.038)] / 1.81=0.412$. Assuming a loan-to-value ratio of 75 percent, the new construction absorbs 31 percent of incremental deposits.

35. Federal Home Loan Bank Board Journal, vol. 13 (September 1980), table S.4.5, p. 46 .

36. The 68 percent is obtained by multiplying the loan-to-value ratio by 90 (see Jaffee and Rosen, "Mortgage Credit Availability," p. 351, note 16). They obtain a similar estimate for financing of multifamily housing even though only 3 percent of loans closed at savings and loan institutions finance new multifamily construction. 


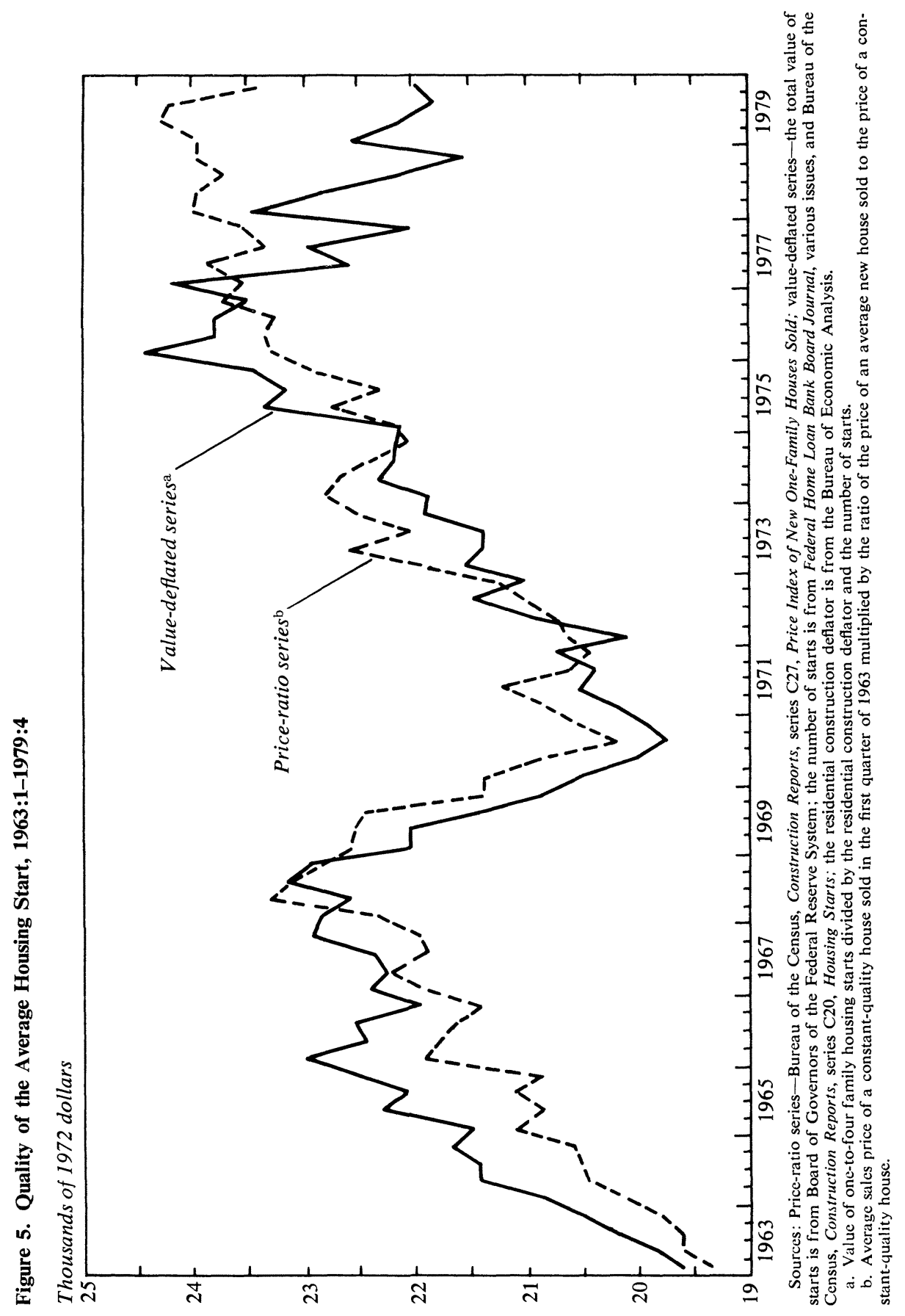




\section{Average Quality of Housing Starts}

The quality of housing desired by each homeowner (based on number of square feet, fireplaces, and other characteristics ), $Q^{*}$, is a function of $y, c$, and $m:^{37}$

$$
Q^{*}=\phi(y, c, m) \text {. }
$$

The rise in $y$ noted above and the decline in $c$ should have increased the quality of the average housing start over time, while the rise in $m$ should have mitigated the increase.

Figure 5 illustrates two measures of the quality of the average housing start. The first is the value of one-to-four family starts divided by the residential construction deflator (equal to 1.0 in 1972) and the number of starts. The second is the ratio of the price of the average new house sold to the price of the constant-quality house multiplied by $\$ 22,700$, the cost of the constant-quality house in $1963: 1$ prices. ${ }^{38}$ The two measures track quite closely for the 1963-77 period; they rise from less than $\$ 20,000$ (1972 prices) in 1963 to $\$ 23,000$ in 1968 , decline to about $\$ 20,000$ in $1970-71$, and climb to about $\$ 24,000$ in late 1976 and early 1977 . The series move quite differently thereafter. The deflated-value series declines sharply, while the price-ratio series rises modestly through 1979:2 and then dips. Both the questionable quality of the value series, which is constructed from data on building permits, and evidence that the quality of single-family houses rose between 1977 and 1979 point toward the priceratio series as the more reliable one. ${ }^{39}$

37. In an early study L. Jay Atkinson explained the average acquisition price for new single-family homes with mortgages issued by the U.S. Federal Housing Administration annually for 1947-64. See "Factors Affecting the Purchase Value of New Houses," Survey of Current Business, vol. 46 (August 1966), pp. 20-36. Regressors included income, the real price of a standardized FHA house, and the initial monthly mortgage payment. All variables performed as expected.

38. The series are published by the U.S. Bureau of the Census, Construction Reports, series C27, Price Index of New One-Family Houses Sold.

39. The median square feet in newly constructed homes rose from 1,535 in 1975 to 1,610 in 1977 and on to 1,645 in 1979. See Census Bureau, Construction Reports, series C25, Characteristics of New Housing, 1979 (U.S. Department of Commerce, 1979), table 15, p. 37. In addition, the percentages of new homes with two or more garages, one or more fireplaces, air conditioning, and two or more baths all rose between 1975 and 1977 and between 1977 and 1979. 
The low real value of the average start in 1970-71 cannot be explained by the underlying income and price variables. Rather, it appears to be attributable to a surge in lower-quality, subsidized single-family starts in that period. If the quality of the average subsidized start equals $Q-X$, where $Q$ is the quality of an unsubsidized start and $X$ is a constant, the quality of the average start, $Q_{A}$, is

$$
\dot{Q_{A}}=Q-X\left(\frac{N_{s}}{N}\right)
$$

where $N_{s} / N$ is the ratio of subsidized starts to total starts. Data on the number of subsidized starts were not readily available, but the value of these starts, $(Q-X) N_{s}$, was. The ratio of this series to the total value of one-to-four family housing starts rose from zero in 1969:1 to 0.147 in $1971: 1$, fell to 0.048 in $1973: 3$, remained in the 0.027 to 0.066 range through 1977:4, and was 0.005 in 1978 . Next, define

$$
S U B=\frac{(Q-X) N_{s}}{Q_{A} N}
$$

Then

$$
Q_{A}=Q-X^{\prime} S U B,
$$

where $X^{\prime}=X\left[Q_{1} /(Q-X)\right]$ and the term in brackets measures the ratio of average quality to subsidized quality. Replacing $Q$ by $Q^{*}$, substituting 7 into 8 , linearizing, and allowing for partial adjustment yields

$$
\Delta Q_{A}=a_{0} \lambda+a_{1} \lambda y-a_{2} \lambda c-a_{3} \lambda m-\lambda X^{\prime} S U B-\lambda Q_{A-1},
$$

where $X^{\prime}$ is now treated as part of the estimated coefficient on $S U B$ and is interpreted to satisfy equation 8 with the other variables at their mean values, and where the $a$ are long-run coefficients and $\lambda$ is the adjustment parameter.

Equations 4-1 and 4-2 in table 4 are estimates of equation 9, after adding $Q_{A-1}$ to both sides, for the two different measures of average quality. As can be seen, the price-ratio series is much better explained than the value-deflated series, although all except one of the coefficients are correctly signed and statistically different from zero. The estimated speeds of adjustment, 0.40 and 0.59 , are quite rapid. The coefficient on 
the $S U B$ variable implies that the average value of subsidized starts was 56 percent of the average value of nonsubsidized starts. ${ }^{40}$ This seems a little low.

The long-run elasticities of the equations in table 4, evaluated at the means, are as follows:

$\begin{array}{cccc} & \text { Real income } & \begin{array}{c}\text { Mortgage-payment } \\ \text { constraint }\end{array} & \text { Real user cost } \\ 4-1 & 0.43 & -0.43 & -0.21 \\ 4-2 & 0.68 & -0.16 & -0.10 \\ 4-3 & 0.47 & -0.23 & -0.18 \\ 4-4 & 0.36 & -0.26 & -0.22\end{array}$

Equation 4-2 uses the preferred quality variable. In that equation, the income elasticity, 0.68 , is close to that estimated from microeconomic data, but the price elasticities, -0.10 for the user cost and -0.16 for the mortgage-payment constraint, are far lower in absolute value than those obtained from microeconomic data. ${ }^{41}$ To test the sensitivity of equation 4-2 to changes in the price elasticities, the equation was reestimated with the coefficient on the user cost constrained to a larger (absolute) value. As equations 4-3 and 4-4 indicate, little explanatory power is lost when the user-cost elasticity is constrained to be twice or more than twice as large. This also raises the elasticity with respect to the mortgage-payment constraint; however, a disadvantage is that the income elasticity falls. The forecast experiments discussed below determine which of the equations in table 4 is to be used in the policy simulations.

\section{Simulation Model}

A number of simulation experiments can be performed to test the viability of the estimated equations, to illustrate their implications, and to

40. From equation $8, \bar{Q}=\bar{Q}_{A}+X^{\prime} \overline{S U B}$, where bars over variables indicate mean values. With $\bar{Q}_{A}=\$ 21,950$ (1972 prices), $\overline{S U B}=0.04$, and $X^{\prime}=17.0$ (from the estimated coefficients in equation 4-2), this yields $\bar{Q}=\$ 22,630$. Solving for $X$ from the definition of $X^{\prime}$ yields $X=\$ 9,880$. Thus the implied mean value of subsidized starts, $\bar{Q}-X$, is $\$ 12,750$.

41. Rosen, "Housing Decisions," p. 15, reports on income elasticity of 0.76 and a price elasticity of -0.96 . The price elasticity does not reflect a response to expected inflation because this variable did not vary across households. 


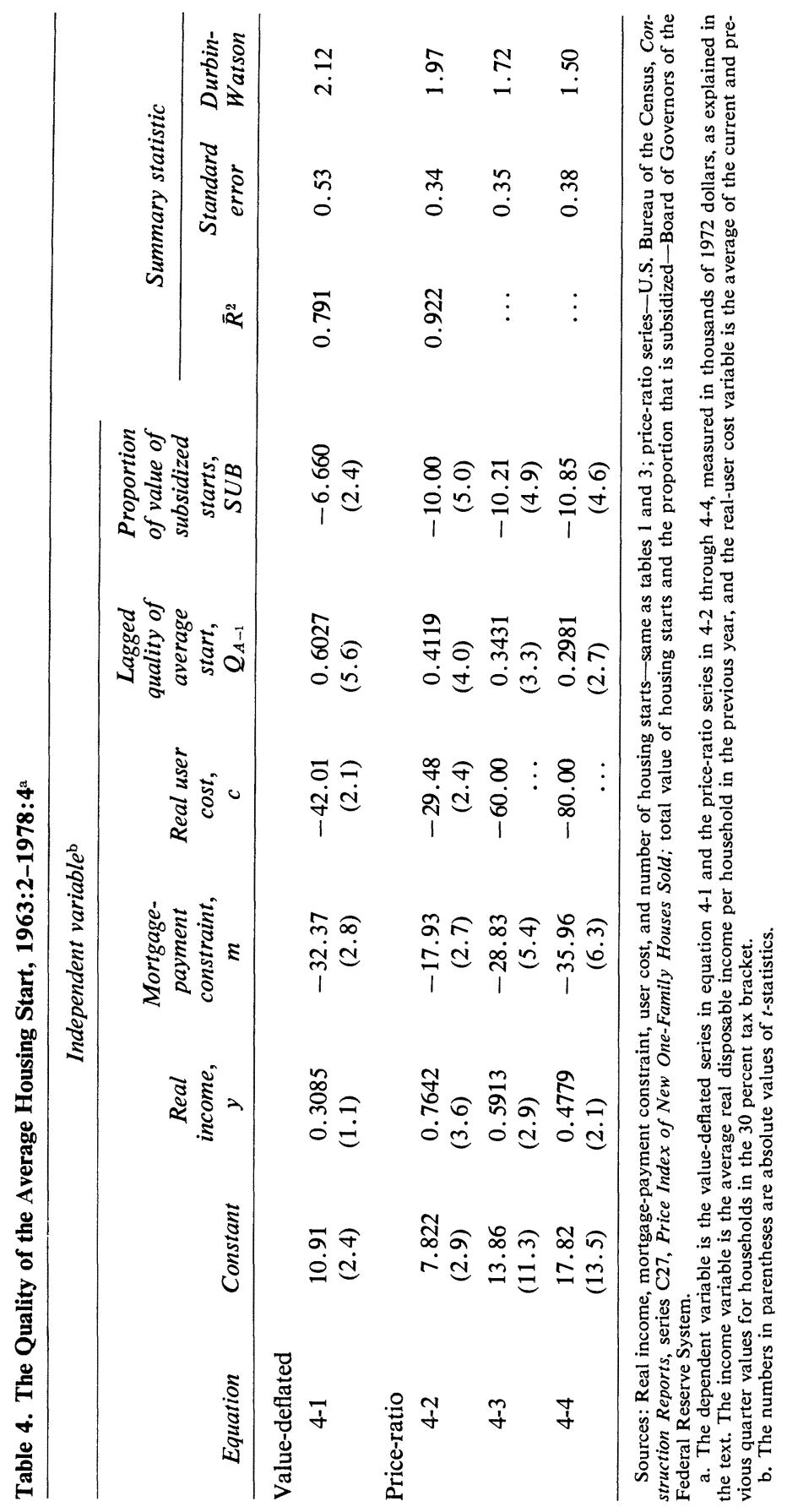


increase understanding of behavior in the housing sector during the past twenty years. These are reported in the following sections. Before describing them, the model is summarized and a few issues regarding its form are addressed.

The housing sector model that will be simulated is shown in figure 6 . The boxes enclosed by double lines contain the three variables that have been explained empirically in equations $1-1,3-3$, and $4-2$. The financial variables that influence the explained variables, which were calculated before the estimation, are enclosed in circles. Note that the variable for credit availability and the mortgage-payment constraint affect the number and quality of starts, respectively, while user costs have an impact on both (the number of starts being influenced by the tenure decision). The proximate determinants of these calculated financial variables are listed at the left of the figure: interest rates, tax law, and the financial structure. Underlying these variables and directly affecting some of the behavioral relations are household formation, productivity growth, and inflation.

Equations to explain the real value of starts and the change in housing stock (at the right of the figure) must still be specified. As already mentioned, the real value of total starts, $H S$, is simply the product of the number of starts and the real value per start. To obtain a relation for the real housing stock, $K$, the following equation was estimated for the period from 1960:2 to $1978: 4$ to translate the real value of starts into the real stock:

$$
\begin{aligned}
& K=1.681+0.1307 H S+0.1252 H S_{-1}+0.0156 H S_{-2}+0.9940 K_{-1} \text {, } \\
& \text { (6.3) } \\
& \text { (7.1) }
\end{aligned}
$$

The coefficients differ slightly from those expected: 1.00 on $K_{-1}, 0.25$ on the sum of the $H S$ coefficients (with the value of starts measured at annual rates), and zero for the constant term..$^{42}$ These expectations are based

42. The numbers in parentheses are $t$-statistics. An alternative, possibly preferred, equation that corrects for autocorrelation and constrains the constant term to zero is

$$
\begin{aligned}
& K=0.0990 H S+0.1272 H S_{-1}+0.0322 H S_{-2}+0.9969 K_{-1}+0.785 R h o, \\
& \text { (6.5) }
\end{aligned}
$$




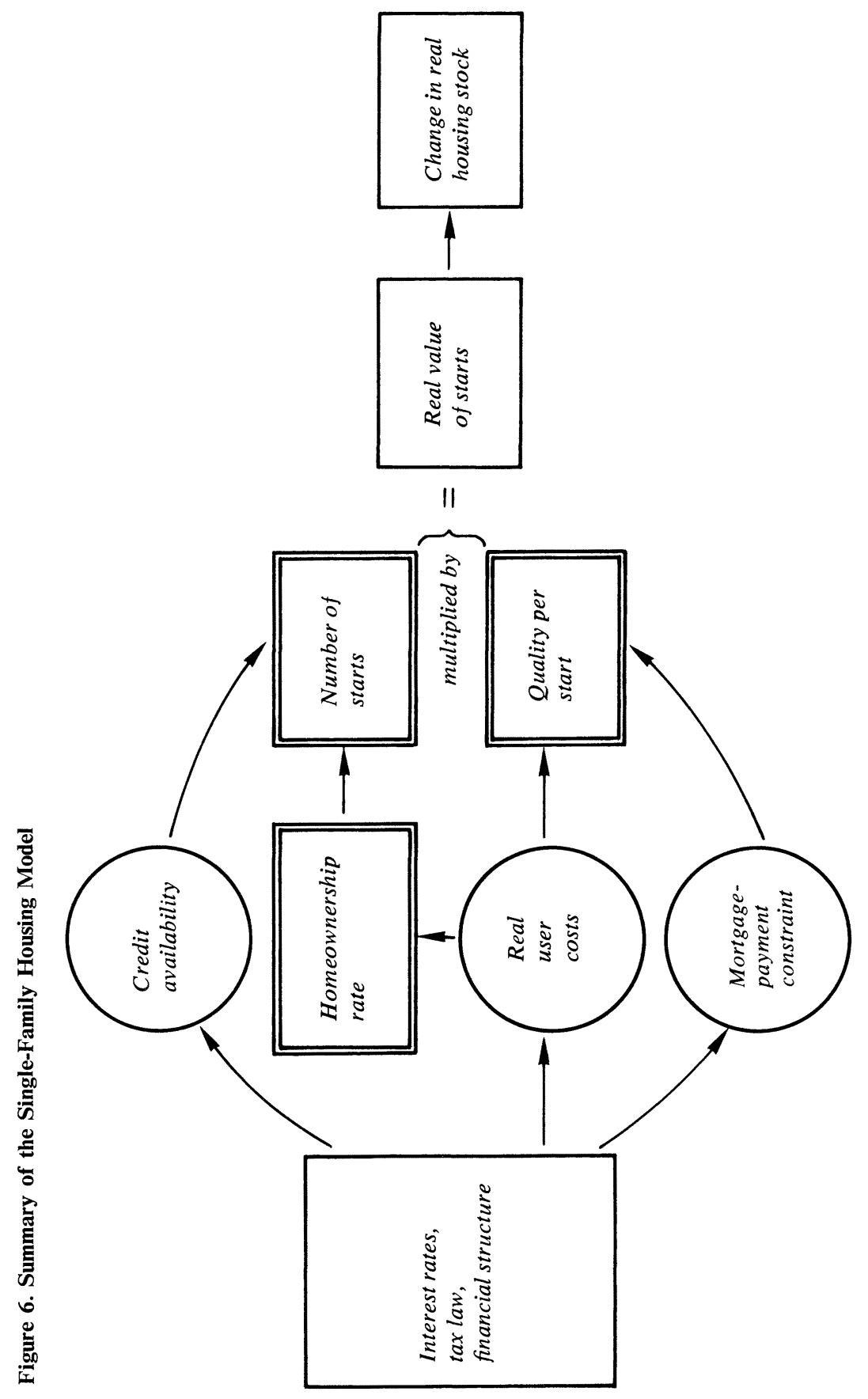


on the fact that real outlays on additions and alterations approximately equal economic depreciation. ${ }^{43}$

The model was not extended to incorporate feedback effects because no relatively straightforward extension seemed useful. The most obvious extension would be to make the relative price of housing endogenous (the price of a constant-quality house divided by the CPI net of shelter). An exogenous increase in the demand for single-family housing might be expected to raise this price, which, by raising both the real user cost, $c$, and the mortgage-payment constraint, $m$, would cushion the increase in demand. ${ }^{+4}$ The difficulty with this extension is that the market for singlefamily housing is not isolated from markets for other structures. ${ }^{45}$ One indication of the substitutability within the construction industry is the close correlations among the series for constant-quality house prices, the deflator for all residential structures, and the deflator for nonresidential structures. For example, between the beginning of 1968 and 1980 these series increased by 178,171 , and 177 percent, respectively. To explain the relative price of structures would require modeling the demands for multifamily housing and nonresidential structures as well as the supply of structures.

The increases in the price indexes for structures mentioned above are much greater than those in indexes of prices of other major components of aggregate output. For example, the increases during the same 1968-80 interval in the deflators for consumer durables, producers' durables, and nondurable consumption, respectively, were only 69, 96, and 120 percent. This may raise questions regarding the extent of simultaneous equations bias in the demand equation for average quality and the absence of the real price of housing from the supply equation for housing starts. My

43. The ratio of the real value of additions and alterations (annual rate) to the real stock of single-family housing was 0.011 for the fourth quarters of 1965,1970 , 1975, and 1978 (data from the Federal Reserve Board). The annual depreciation rate for residential housing during the 1950-70 period was recently estimated to be 0.010. See Wilhelmina A. Leigh, "Economic Depreciation of the Residential Housing Stock of the United States, 1950-70," Review of Economics and Statistics, vol. 62 (May 1980), pp. 200-06.

44. James R. Kearl, "Inflation and Relative Price Distortions: The Case of Housing," Review of Economics and Statistics, vol. 60 (November 1978), pp. 60914.

45. See Craig Swan, "Labor and Material Requirements for Housing," $B P E A$, 2:1971, pp. 347-77, and William E. Gibson, "Protecting Homebuilding from Restrictive Credit Conditions," BPEA, 3:1973, pp. 647-91. 
Table 5. Determinants of the Rise in the Real Price of Structures, Demand, Selected Periods, 1955-79

Percent

\begin{tabular}{cccc}
\hline Period & \multicolumn{2}{c}{$\begin{array}{c}\text { Share of real outlays on } \\
\text { structures in real GNP }\end{array}$} & $\begin{array}{c}\text { Change in the ratio of } \\
\text { structures deflator } \\
\text { to GNP deflator }\end{array}$ \\
\cline { 2 - 4 } Residential & Total & -2.0 \\
$1955-59$ & 4.78 & 8.74 & -7.0 \\
$1960-64$ & 4.82 & 8.65 & 4.0 \\
$1965-69$ & 3.98 & 8.12 & 11.0 \\
$1970-74$ & 4.37 & 8.08 & 11.0 \\
$1975-79$ & 3.83 & 6.94 & \\
\hline
\end{tabular}

Source: Economic Report of the President, January 1980, tables B-2, B-3, pp. 204-07. The structures deflator is measured as a simple average of the deflators for residential and nonresidential structures.

treatment has implicitly assumed that the rise in the real price is determined by supply, not demand, factors and thus the real price is largely exogenous to household demand and irrelevant to builders' supply. This treatment contrasts markedly with recent work by Lawrence Summers and James Poterba in which the rise in the real price is assumed to be demand induced and is modeled as the primary determinant of the supply of housing. ${ }^{46}$ Although the data in tables 5 and 6 are not conclusive, they support the supply view of the rise in the real price. Table 5 shows that the real price declined when outlays for real structures were a relatively large portion of real GNP and that the recent rise in real price has been accompanied by a relative decline in the production of structures. Table 6 indicates that the movement in the real price is negatively correlated with the productivity growth in the construction industry relative to overall productivity growth. During the $1950-65$ period, construction showed above-average productivity growth, and the real price of structures fell; since then construction has had below-average productivity growth, and the real price has risen.

46. Lawrence H. Summers, "Inflation and the Valuation of Physical Assets," paper presented at the 93d Annual Meeting of the American Economic Association, Denver, September 6, 1980; and James M. Poterba, "Inflation, Income Taxes, and Owner-Occupied Housing," Working Paper 553 (National Bureau of Economic Research, Cambridge, Massachusetts, September 1980). Neither Summers nor Poterba allow for supply substitution between single-family housing and other structures, and Poterba's estimated price response appears to be dependent on an unbelievably large credit rationing effect $-\$ 1.5$ billion of new single-family construction for $\$ 1$ billion of additional deposits. 
Table 6. Determinants of the Rise in the Real Price of Structures, Supply, Selected Periods, 1950-77

Percent

\begin{tabular}{cccc}
\hline & \multicolumn{2}{c}{ Annual rate of productivity growth } & $\begin{array}{c}\text { Change in the ratio of } \\
\text { structures deflator } \\
\text { to GNP deflator }\end{array}$ \\
\cline { 2 - 4 } Period & Construction & All industries & -7.0 \\
$1950-65$ & 3.4 & 2.7 & 10.0 \\
$1965-73$ & -2.1 & 2.0 & 10.0 \\
$1973-77$ & 0.3 & 1.1 & \\
\hline
\end{tabular}

Sources: Productivity-Economic Report of the President, January 1979, table 16, p. 71 ; ratio of structures to GNP deflator-Economic Report of the President, January 1980, table B-3, pp. 206-07. The structures deflator is measured as a simple average of the deflators for residential and nonresidential structures.

A second important feedback effect works through interest rates. To illustrate, an exogenous increase in the demand for housing will raise interest rates, choking off some of the increased housing demand and the demands for other capital. Allowing for the feedback of interest rates requires modeling all demands for capital (and saving to the extent that it is not independent of interest rates). In fact, either a full macroeconomic model must be used or, perhaps more reasonably, the Federal Reserve can be assumed to offset the macroeconomic effects of the initial increase in demand by raising real interest rates (and so made endogenous) ${ }^{47}$ Analysis, including feedbacks, is postponed until a later date. The simulations reported below should be viewed as partial equilibrium calculations and provide upper bounds on the estimated effects operating through demand.

\section{FORECASTS OF HOUSING DEMAND, 1979-80}

The period following the estimation, 1979:1-1980:2, provides a challenging forecast test. The real value of total housing starts remained about the same during the first three quarters of 1979 and then plummeted. The decline was largely in the number of starts, which were at only

47. See Patric H. Hendershott, "Model Simulations of the Impact of Selective Credit Policies and Financial Reforms: The Appropriate Monetary-Policy Assumption," Journal of Banking and Finance, vol. 1 (September 1977), pp. 173-84; and

$\rightarrow$ Hendershott, "Analysis of the Impact of Capital-Specific Policies or Legislation: Application to Reforms of the Tax-Exempt Market," Journal of Money, Credit, and Banking, special issue, Financial Market Behavior, Capital Formation, and Economic Performance, vol. 12 (May 1980), pp. 377-99. See also, Ray C. Fair, "The Sensitivity of Fiscal Policy Effects to Assumptions about the Behavior of the Federal Reserve," Econometrica, vol. 46 (September 1978), pp. 1165-79. 


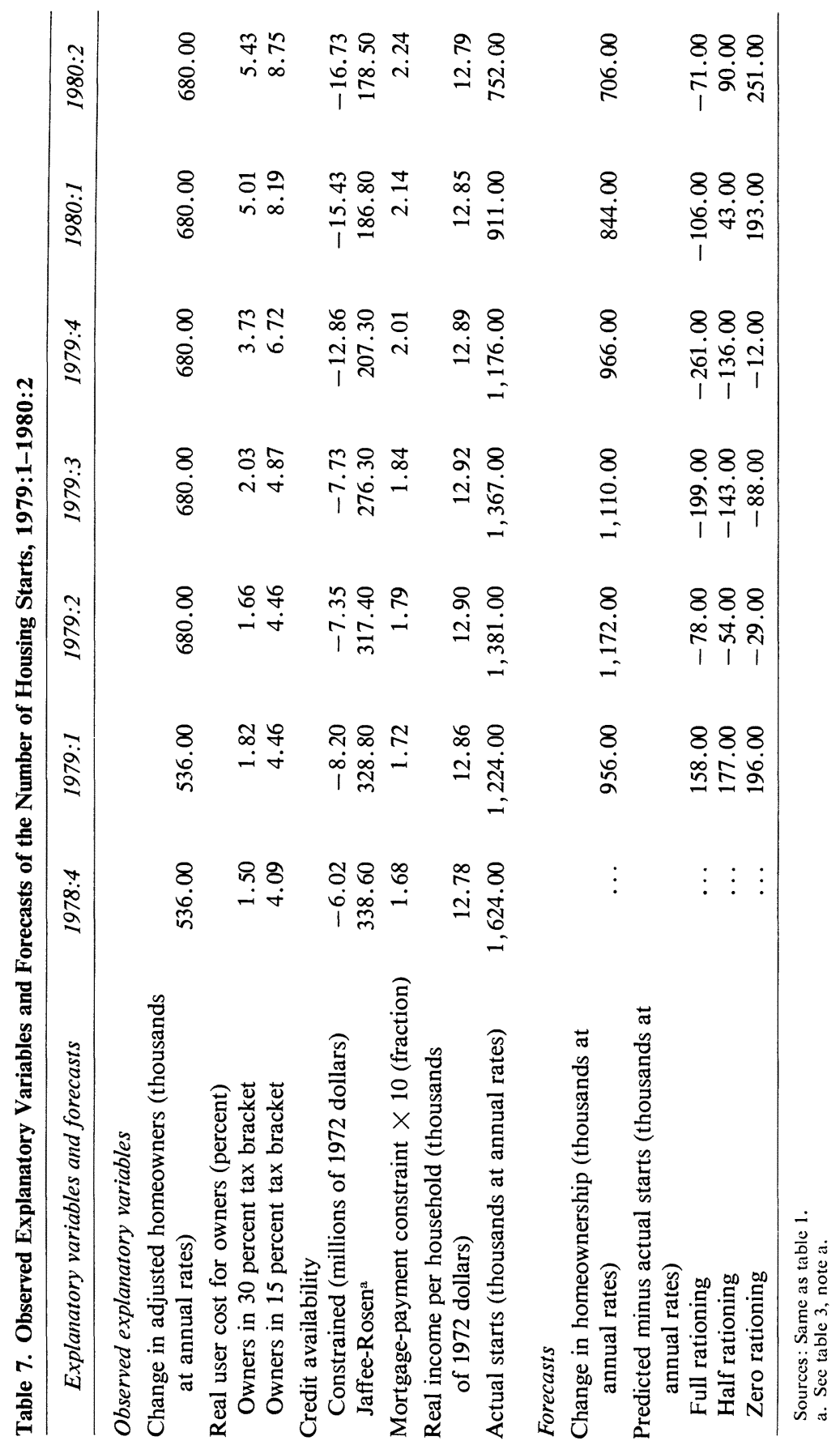


half the 1978 average in 1980:2; the real value per start, in contrast, was only down by 5 percent. Also, the real after-tax mortgage rate, and thus the real user cost, rose sharply for the first time in almost half a century, and the mortgage-payment constraint increased to an unprecedented level.

Table 7 contains forecasts of the number of one-to-four family housing starts, divided into two parts. The first presents observed values of the key explanatory variables for the 1978:4-1980:2 period. The forecast of the number of starts depends significantly on projected future changes in the number of adjusted homeowners. The last available calculation of adjusted homeownership is for 1979:1. For the remaining quarters, the change was set at the sample mean, that is, 680,000 at an annual rate. The second part reports the predicted change in homeownership and the difference between the predicted and the actual numbers of housing starts under a variety of assumptions about the importance of credit rationing in the cycle. These assumptions are that the impact of the rationing variables in the cycle was (1) the same as in earlier cycles, (2) half as great, or (3) nonexistent. ${ }^{48}$ These are equivalent, respectively, to the assumptions that the mortgage market was (1) no more integrated with capital markets generally than in the early and middle 1970s (full rationing), (2) half integrated (half rationing), or (3) fully integrated (zero rationing).

Housing starts fell from $1,624,000$ at an annual rate in 1978:4 to 752,000 in 1980:2 with 615,000 , or 70 percent, of the decline occurring after 1979:3. The full-rationing model underpredicts starts in every quarter except 1979:1; the cumulated error for the six quarters (divided by four) is 139,000. The sharp drop in starts in 1979:1 has been attributed by Jaffee and Rosen to a particularly severe winter, ${ }^{49}$ and an equation

48. These assumptions are implemented by adjusting the equation for housing starts. The estimated equation in table 3 is of the form

$$
S T=\alpha^{e} A A+\beta^{e} J R A A+\ldots,
$$

where the superscript denotes estimated coefficients. This equation is equivalent to

$$
S T=\alpha A A+\beta^{e} 329+\gamma(J R A A-329)+\ldots,
$$

where $\alpha=\alpha^{e}$ and $\gamma=\beta^{e}$ (329 is the 1979:1 value of $J R A A$ ). This is the full-rationing (zero-integration) equation. The half-rationing equation is obtained by setting $\alpha=\alpha^{e} / 2$ and $\gamma=\beta^{e} / 2$. The equation for zero rationing has $\alpha=\gamma=0$.

49. Jaffee and Rosen, "Mortgage Credit Availability," p. 362. Jaffee and Rosen state that the impact of the unusually harsh weather was perceived by housing experts to have reduced single-family starts by about 300,000 . They further argue that these starts would not be made up in the following quarter. 


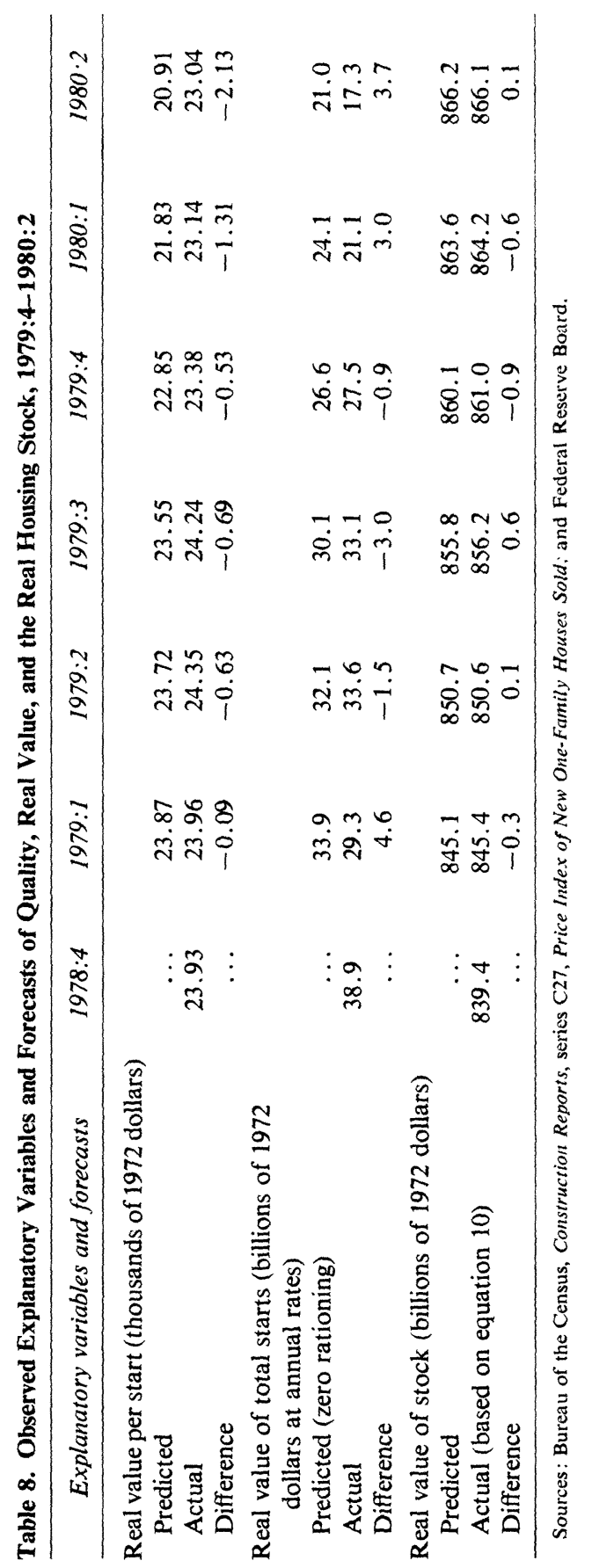


should not be expected to capture the impact of such an event. Thus the full-rationing model consistently and significantly underpredicts starts.

The equation for half rationing appears to forecast best; the positive and negative errors about cancel, leaving a cumulative error of only 6,000. However, the expected overprediction in 1979:1 has already been noted, and $I$ argue below that the equation would also be expected to overpredict in 1980:1 and 1980:2. Thus in the only quarters that I would expect the equation to forecast accurately, 1979:2-1979:4, the equation underpredicts. This suggests that even half rationing may be too large an impact. The equation for zero rationing contains the same pattern of errors, but the underpredictions in the 1979:2-1979:4 period are much smaller and the overpredictions in 1980:1 and 1980:2 much larger. Even though this equation leads to a cumulative overprediction of 128,000 , I think it best captures the impact of the phenomena it was designed to capture. The severe weather in 1979:1 explains the overprediction, and the unprecedented strong expectations in 1980:1 and 1980:2 that interest rates would decline shortly can explain these errors (see below). Although the evidence is somewhat cloudy, it seems consistent with the view that rationing was not a factor in the most recent housing recession. ${ }^{50}$

Table 8 contains three parts: forecasts of the real value per start, total real value of starts (the product of the number and real value per start), and real one-to-four family housing stock. These forecasts are dynamic in the sense that the predicted lagged quality of the average housing start is used in the calculations after 1979:1. The predicted real value of starts uses the predictions of starts that assume zero rationing.

The average quality per start rose by $\$ 400$ (1972 prices) in 1979:2 from the preceding quarter and then declined by a total of $\$ 1,300$ through 1980:2. The forecast misses the rise in 1979:2 and then overstates the decline in 1980 by 1,600 - that is, the estimated equation implies that the sharp increases between $1979: 3$ and 1980:2 in the mortgage-payment constraint (0.040) and the user cost (0.034) should have lowered the average quality by even more than they did.

50. Much of the cloudiness is because of the uncertainty regarding the change in the number of adjusted homeowners. If the actual change were at the low end of the 1975-78 experience, 520,000 at an annual (1978) rate, even the equation for zero rationing would underpredict cumulative starts by 59,000 . On the other hand, if the actual change in adjusted homeownership were at the high end of recent experience- 840,000 - then the equation for zero rationing would overpredict starts by 63,000 , but the equation for half rationing would underpredict. 
An explanation for both the underprediction of the quality of starts and the overprediction of the number of starts that occurs once the availability variable is fully suppressed in the equations is that the extraordinarily high mortgage rate in late 1979 and early 1980 was not expected to remain at that level for long. The mortgage rate rose sharply from 11.25 percent in $1979: 3$ to 15.21 in 1980:2 (and peaked at 16.56 in April 1980).${ }^{51}$ At the same time, the yield curve for U.S. Treasury securities became inverted to an unprecedented extent. While the U.S. short-term (one-year) rate normally rises above the long-term rate in the late stages of the business cycle, the spread has historically been only 50 to 100 basis points (late 1966 and about midyear in 1969, 1973, and 1974). In contrast, in late 1979 the spread exceeded 200 basis points, and in early 1980 it was over 300 points. This suggests that investors and borrowers were expecting significant declines in interest rates. (The mortgage rate rose as high as it did because both borrowers and lenders viewed it as a relatively short-term rate.) This might be expected to have had two effects. First, some potential buyers probably delayed their purchase or order of new construction, a fact that can explain starts being lower in 1980 than in the forecast. Second, home buyers who went ahead with their purchase or order should not have lowered the quality of their purchase in line with the high mortgage rates. They expected to be able to refinance at lower rates in the near future, and it is the average mortgage rate expected to be paid over the lifetime of the investment that belongs in the user-cost calculation. To account for the latter expectation, I arbitrarily dampened the increase in the mortgage rate in late 1979 and the first half of 1980. The substitution of the real user-cost and mortgagepayment constraint variables based on a smaller rise in the mortgage rate, 11.32 to 13.25 , for those listed in table 7 raises the quality of the average start by $\$ 300$ in $1979: 4, \$ 600$ in $1980: 1$, and $\$ 900$ in 1980:2. Nonetheless, the equation still underpredicts the quality of the average start in $1980: 2$ by more than $\$ 1,000 . .^{52}$ Forecasts based on an equation with

51. Effective rate on conventional home mortgage loans with twenty-five year maturity, national average for all major types of lenders, at 75 percent loan-to-price ratio. See Federal Home Loan Bank Board Journal, vol. 13 (September 1980), table S.5.2, p. 51.

52. Another possible explanation for the underprediction is that the time needed for adjustment to the unprecedented increases in the price variables may be longer than the implied speed of adjustment in the estimated equation. 
greater price elasticities, such as equations 4-3 and 4-4, would generate even larger errors. Thus 4-2 is used in the policy simulations below.

Even with the above dampening of the price variables, the equation for average quality predicts an average start that is $\$ 2,500$ lower in quality in 1980:2 than it was a year earlier. However, a structural change has recently occurred that should dampen such a decline in quality. In November 1976 the FHA began insuring graduated-payment mortgages with five alternative plans. Although the plans all had graduated payments, none has significantly reduced financial constraints on home buyers. The initial loan on the most popular of these plans was 90.4 percent of the original purchase price, and the highest eventual outstanding loan balance after five years was 97 percent of the initial house value. The alternative was a 96 percent initial loan on a fixed-payment mortgage. In effect, the lower early mortgage payments on the graduated-payment mortgages came at the expense of a higher percentage down payment, nearly 10 percent instead of the 4 percent customarily put down on small FHA mortgages. Households could have created this graduated-payment mortgage on their own by putting 4 percent down, investing the other 6 percent in liquid assets, and using the liquid assets and income from them to pay part of the monthly payments during the first five years. But a new program introduced July 1, 1980, promises to reduce the financial constraints. Under this plan a down payment of only the customary 4 percent is required and monthly payments rise at an annual rate of 4.9 percent for the first ten years. In the eighth year the outstanding loan peaks at 110 percent of the initial house price. Under this plan the payments in the initial year on a thirty-year mortgage are a full 25 percent below those on an otherwise similar level-payment mortgage. That is, the fraction of disposable income absorbed by net tax mortgage payments would decline from 0.1975 (based on a $12 \frac{1}{2}$ percent mortgage) to 0.1481 . According to my best estimates, if all credit-constrained borrowers were able to obtain such mortgages, the average quality per start would rise by $\$ 1,500$ (1972 prices).

The last two parts of table 8 translate the forecasted starts and quality per start into the real value of starts and the real housing stock. These forecasts are based on the zero-rationing, full-integration forecasts of starts. The errors in the real-value forecasts largely reflect errors in the number of starts, although the errors in quality per start in 1980 act as a 
partial offset. Given that the errors in starts and quality per start in 1980 are offset, the only large error in real value is in 1979:1. The real value of the stock of housing is tracked closely; the error is always less than $\$ 1$ billion.

\section{Policy Simulations}

The two policy simulations reported are attempts to determine the longterm (1964-79) impact of the increase in inflation on the real stock of one-to-four family housing and the roles of the various financial variables in the housing cycles since 1965 .

\section{INFLATION AND THE FAVORED TAX TREATMENT \\ OF SINGLE-FAMILY HOUSING}

The real user cost of capital for owner-occupied housing of households in the 15 percent tax bracket declined from just under 8 percent in the early 1960 s to 4 percent in 1978 . This drop follows directly from a sharp fall in real after-tax interest rates. Rates do not appear to have increased by even as much as expected inflation, much less by the multiple increase needed to maintain real after-tax rates. In contrast, the real user cost for rental housing and thus the equilibrium rental cost fell by only about 1.5 percentage points during the same period. The use of historical cost depreciation in an infiationary period and the passage of legislation that increased taxation of investments in rental housing have acted to offset, in large measure, the decline in real after-tax financing rates. As a result, homeownership has been encouraged.

The impact of rising inflation on the quality of housing demanded is less clear. The decline in the real user cost has, of course, encouraged investment in relatively larger houses, but the sharp rise in the ratio of initial mortgage payments to income has restricted the quantity of feasible investment. Thus the quality of starts (and the growth rate of the housing stock) could have been higher or lower.

To calculate the impact of rising inflation in the given tax environment on the stock of single-family housing, a simulation was run for the 1964: 2-1979:4 period in which the ratio of the real user cost for owneroccupied housing to that for rental housing was maintained at 0.7847 ; the 
real after-tax mortgage rate incorporated in the user cost for homeowners in the 30 percent tax bracket was held at 0.0308 ; and the nominal, aftertax mortgage rate built into the mortgage payment variable was maintained at 0.0408 . All these were observed 1964:1 values. In addition, the equation for housing starts was modified so that it would fully reflect policy-induced changes in homeownership..$^{53}$

The simulation results imply that inflation has raised the real singlefamily housing stock by about 15 percent, or from $\$ 744$ billion to $\$ 856$ billion (1972 prices). The observed increase in the 1964:2-1979:4 period, $\$ 261$ billion, was 75 percent more than it would have been in the absence of the favorable taxation of owner-occupied housing. The quality of the average start was increased by $\$ 1,000$ (1972 prices) by 1968 (an increase of about 5 percent), remained $\$ 500$ to $\$ 1,500$ greater through 1976 , and was more than $\$ 2,000$ (or 10 percent) greater from late 1977 through the first half of 1979 . The cumulation of this differential in quality during the 1964:2-1979:4 period accounts for $\$ 33$ billion of the $\$ 111$ billion total increase attributable to rising inflation. Most of the increment was due to the 4.5 million increase in the number of homeowners and thus single-family housing starts.

\section{DETERMINANTS OF RECENT SINGLE-FAMILY}

\section{HOUSING CYCLES}

The simulation experiments summarized in table 9 are designed to identify the roles in all housing cycles since 1965 of the key variables of real

53. Recall that the starts equation is of the form

$$
S T=\alpha_{1} A C H O A+\alpha_{2} A C H O+\alpha_{3} L R U C+\ldots,
$$

where the first term is the projected average four-quarter change in adjusted homeownership; the second term is the observed current average four-quarter change in homeownership; and the last term reflects a response to the long-run change in homeownership based on differences between the weighted average past ratio of user costs and the current ratio. The estimated equation has the property that the mean of the sum of the three terms is about equal to the mean change in homeownership. However, in this policy simulation the reduction in homeownership caused by prevention of a decline in the user-cost ratio will not reduce starts onefor-one because $\alpha_{2}$ is far below unity. The equation was modified to

$$
S T=\alpha_{1} A C H O A+\alpha_{2} A \widehat{C H O}+\alpha_{3} L \widehat{R U C}+1.0(A C H O-A \widehat{C H O})+\ldots,
$$

where $A \widehat{C H} O$ and $L \widehat{R U C}$ are the control-calculated values of $A C H O$ and $L R U C$. ( $A C H O A$ is exogeneous.) Thus policy-induced changes in $A C H O$, that is $A C H O-$ $A \widehat{C H} O$, will affect starts one-for-one. 
Table 9. Determinants of Single-Family Housing Production Cycles, Selected Periods, 1965:2-1980:2

Billions of 1972 dollars

\begin{tabular}{|c|c|c|c|c|c|}
\hline \multirow[b]{2}{*}{ Period $^{\mathrm{a}}$} & \multirow[b]{2}{*}{$\begin{array}{c}\text { Real value } \\
\text { of housing } \\
\text { starts }\end{array}$} & \multirow[b]{2}{*}{$\begin{array}{l}\text { Change from } \\
\text { previous }^{\text {period }} \\
\text { b }\end{array}$} & \multicolumn{3}{|c|}{ Amount due to change in variable } \\
\hline & & & User cost & $\begin{array}{l}\text { Mortgage- } \\
\text { payment } \\
\text { constraint }\end{array}$ & $\begin{array}{c}\text { Credit } \\
\text { availability }\end{array}$ \\
\hline \multicolumn{6}{|l|}{ Housing recessions } \\
\hline $1966: 3-1967: 2$ & 17.3 & -4.8 & 2.3 & -0.1 & -1.9 \\
\hline 1969:4-1970:3 & 17.5 & -4.9 & 0.3 & -0.4 & -2.4 \\
\hline $1974: 3-1975: 2$ & 19.1 & -12.8 & 3.8 & -0.5 & -6.3 \\
\hline 1980:1-1980:2 & 19.2 & -17.9 & -12.2 & -0.9 & $-1.2^{\mathrm{c}}$ \\
\hline \multicolumn{6}{|l|}{ Housing booms } \\
\hline 1965:2-1966: 1 & 22.1 & .. & .. & $\cdots$ & $\cdots$ \\
\hline 1968:1-1968:4 & 22.4 & 5.1 & 0.5 & -0.2 & 2.4 \\
\hline 1972:3-1973:2 & 31.9 & 14.4 & 1.6 & -0.3 & 5.9 \\
\hline $1977: 3-1978: 2$ & 37.1 & 18.0 & 5.4 & -1.0 & 7.2 \\
\hline
\end{tabular}

Source: Simulations by the author. For the real value of starts see sources of table 4 .

a. Housing booms and recessions are defined as the highest and lowest four quarters of the real value of single-family housing starts, with the exception of the 1980:1-1980:2 recession.

b. For recessions, change from previous housing boom; for booms, change from previous recession.

c. Based on no restrictive availability effect in 1980 . If a full impact of the availability variable were allowed, this figure would be -8.4 .

user cost, mortgage-payment constraint, and credit availability. Four simulations were run for the $1965: 2-1980: 2$ period. The first was a control run. The three policy runs maintained (1) the mortgage-payment constraint equal to its $1964: 1$ value of 0.08531 , (2) the user cost for taxpayers in the 30 percent bracket equal to 0.0599 and for those in the 15 percent bracket equal to 0.7848 multiplied by the rental user cost, both of these being 1965:1 values, and (3) the constrained creditavailability variable equal to zero and the Jaffee-Rosen variable equal to 0.1718 for $1964: 2-1971: 1$ and 0.271 for $1971: 2-1980: 2$. The contribution of, say, the real user cost to a particular housing recession is calculated as the impact of the user cost in the recession (control minus policy) minus the impact in the previous boom (control minus policy). The table shows the actual real value of starts during each period, the actual change from the previous boom or recession, and the measured impacts of the financial variables. The sum of the measured impacts differs from the actual change because of changes in other variables (real income, number of households, and portion of starts that are subsidized), interactive effects, and errors in the equations. 
The following points summarize the impacts that the three variables had on housing. First, the almost continual decline until 1979-80 in the real user costs generated a continual shift toward homeownership and houses of higher quality. Thus single-family housing production tended to be greater in each period until 1979-80, regardless of whether it was a housing boom or a recession. Second, the almost continual rise in the home mortgage rate and real price of houses has exerted a continuously increasing constraint on a shift to houses of higher quality. Hence housing production tends to be lower in each period, whether it is a housing boom or a recession. Third, credit availability has an asymmetric impact on booms and recessions. Abundant credit availability has always stimulated starts during booms, and a lack of availability has restricted starts in all housing recessions until 1979-80. Even when starts are not being restricted, as is assumed to have been the case in 1979-80, credit availability has a negative impact relative to the earlier stimulation.

Two facets of the impact of the user-cost variables stand out. Because the user costs declined more rapidly since 1972 than before then, the impacts, $\$ 3.8$ and $\$ 5.4$ billion, in the two periods following (1974:3$1975: 2$ and 1977:3-1978:2) are substantially larger than those in the early periods. Much of the boom in single-family housing in the middle and late 1970 s was attributable to the user-cost variable. At least equally important is the negative impact of the user cost in the most recent housing recession. Possibly because of a more resilient financial system-the forecasts suggest that the mortgage market had become fully integrated with capital markets generally - the monetary authorities were able, or were compelled, to raise interest rates by unprecedented magnitudes and speed. Moreover, mortgage rates moved faster and more than bond rates. (Never again are stories about the sluggishness or stickiness of mortgage rates likely to be heard.) As a result, real after-tax mortgage rates, and thus the user cost of housing capital, rose sharply for the first time in memory.

\section{Conclusions}

The increase in inflation during the 1964-79 period, in conjunction with the U.S. tax system, has had a marked impact on the demand for housing. My results suggest the following. The sharp decline in the implicit 
rent of owner-occupied housing relative to that of rental housing led about 4.5 million additional households to own rather than rent. The decline over the same period in the rental price of owner-occupied houses relative to prices of other consumer goods led to the demand for significantly larger houses. Despite a doubling of the real initial mortgage payment on a constant-quality house, the quality of houses built in the period from late 1977 to early 1979 was 10 percent higher than it would have been in the absence of the inflation-induced decline in the real rental price of owneroccupied housing (and rise in mortgage rates). The real housing stock was $\$ 33$ billion (1972 prices) greater in 1979 because of this quality effect. ${ }^{54}$ At 1979 house prices, the impact is twice as large.

Between 1965 and 1976 the dominant determinant of housing cycles was the availability of funds at traditional mortgage-financing institutions and the activity of federally sponsored credit agencies. Changes in the real rental price of housing were not a cyclical factor because this price had not moved cyclically. The 1979-80 housing recession constituted a sharp break in this pattern. The unprecedented swiftness and magnitude of the rise in mortgage rates caused the first significant rise in real after-tax mortgage rates in decades. As a result, the real rental price of owner-occupied housing rose sharply, leading builders to forecast a future decline in the demand for owner-occupied units. Moreover, the expectation (reflected in the severe inversion of the yield curve) that mortgage rates were only temporarily high led to a delay in orders by households for new units. These two responses alone can explain the sharp fall in starts. That is, forecasts of the 1979:1-1980:2 period are more plausible when declines in the traditional measures of credit availability are given no weight. Thus it appears that the expansion of secondary mortgage-market instruments and activity in the second half of the 1970s have largely, if not fully, integrated the mortgage market with capital markets generally. As a consequence, credit availability is unlikely to be a major factor in housing cycles in the future.

54. Barry P. Bosworth has suggested that the decline in the real rental price of owner-occupied units may have increased household formation itself by one million. At an average housing unit price of $\$ 20,000$ (1972 prices), this would give an additional $\$ 20$ billion of housing. Adding this to the $\$ 33$ billion and converting to 1979 house prices would raise the total impact on the housing stock to over $\$ 100$ billion in 1979 prices. 


\section{Comments and Discussion}

Barry P. Bosworth: This is a useful empirical paper because it provides a synthesis of several determinants of housing demand that previously have been examined by Patric Hendershott and others on a more individual basis. These include a sophisticated treatment of demographic variables; inclusion of a role for credit rationing; a user cost of capital as a means of evaluating the impact of tax policy, interest rates, and inflation; and a mortgage-payment constraint. These factors are examined within a threeequation recursive model. The model begins by predicting the proportion of households that is homeowners; then, from the number of homeowners predicts the number of one-to-four family units built; and, finally, explains the average value per unit started. I found the first several sections on tenure choice very informative; but I have some concerns with parts of the paper relating to housing starts.

Hendershott takes the total number of households to be predetermined. Yet the Census Bureau's definition of a household is those individuals who occupy a housing unit. It counts the occupied portion of a version of the housing stock, which differs from the conventional stock by the inclusion of mobile homes and the exclusion of vacation homes. The number of households is, therefore, more nearly a measure of the existing housing stock than a demographically determined characteristic of the population; and households cannot be assumed to be predetermined in a model that seeks to explain the change in the number of housing units. In fact, an inspection of the annual survey shows a pronounced slowing of household formation in each of the postwar housing crunches. In these periods, marriages are postponed, children delay leaving home, and individuals double up to share dwellings. As a result, the use of households in the denominator of the homeownership ratio implies at least some prob- 
lems of common endogenous changes in housing starts and households that is only partially eliminated by the lag structure.

I was somewhat confused by the portion of the paper that discusses housing demand-that is, I do not understand the assumption that the demand for homeownership is equivalent to the demand for one-to-four family units. This relation is introduced in the section on the number of units started, where the stock of these family units is defined as homeowners minus owners of "condominiums" plus rentals of these family units and vacancies. Hendershott suppresses this problem of mapping tenure choice into type of unit, however, by assuming that the fractions accounted for by condominiums on the one hand and renters on the other are relatively constant. In fact, he does admit to some year-to-year variations in these ratios. In addition, the ratios do have a trend.

This issue of tenure (homeownership or rental) versus structure type (one-to-four family or multifamily) is also revelant to another issue. Hendershott states that the tax laws in combination with inflation have acted to increase homeownership. With this I agree. A related issue is whether the combination of inflation and the tax laws have increased investment of the nation's resources in housing. One way this might show up in the data is that people would desire a bigger house. Yet Hendershott correctly emphasizes that increased mortgage payments have acted as a powerful offset. Many people were induced to become homeowners rather than renters but that will affect total housing only if rental units imply smaller units. Although this is true, the actual difference in unit values of single-family and multifamily units reflects many factors besides the ratio of user cost of homeownership versus rental. In addition, if the current number of households and the demographic projections prepared in 1970-71 are compared, it is clear that inflation and taxes have not generated a major increase in the number of households.

The share of national output devoted to housing has declined during the 1970 s despite an acceleration of the demographic determinants. Furthermore, despite the fact that the United States has the fastest population growth of the major OECD countries, it is among the lowest in the share of output in residential construction. This is not consistent with the view that the interaction between inflation and the tax laws has led the United States to overinvest in housing at the expense of business investment. Homeownership has risen because of the tax-inflation interaction but the effect of that interaction on total home building has been much smaller. 
I think some of this inconsistency can be resolved, however, by inclusion of the value of land and by placing a greater emphasis on supply factors. Land as well as quality of the structure is a major dimension in which we should expect the asset demand for housing to be reflected. Changing local zoning restrictions have in the 1970 s created a much more rigid supply of housing than in earlier decades. Thus much of the asset demand for housing has been reflected in a bidding up of land prices rather than in diverting other resources from competing uses. I do not believe that the user-cost concept for evaluating the effects of inflation and taxes can be used within a model that ignores the land component of housing, because land prices have not risen at the same rate as the price of structures. For example, home prices, excluding land, rose 60 percent more than the general price level between 1972 and 1979; including land, those prices rose twice as much as other prices.

Dwight M. Jaffee: It is with a sense of déjà vu that I discuss Patric Hendershott's paper. Kenneth Rosen and I presented our paper on the subject at these meetings just one year ago before the dramatic decline in housing that Hendershott reports. We concluded that paper with the warning that "under the pressure of high short-term interest rates ... a more traditional, sharper cyclical decline in housing starts may develop during late 1979 and early 1980." Well, that has come true with a vengeance, particularly during the spring of 1980 , which brought fully disrupted capital markets and a record-breaking decline in housing starts.

There is no denying the author's primary general conclusion, that monetary policy caused the housing recession, overriding in the process a strong underlying demand for housing and a number of developments in mortgage and deposit markets favorable for housing finance. At this level, however, what is missing in the paper is the dramatic tale of the remarkable 1980 episode for U.S. monetary policy and its impact on housing. Specifically, Hendershott emphasizes that the 1980 tailspin of housing starts occurred in the absence of a credit crunch. In my view, the 1980 credit crunch will rank among the best-such as the crunch of 1966-albeit it is something of a new breed, as Albert Wojnilower characterizes it very well in his paper in this issue.

Hendershott's position on the credit crunch leads him to ignore any

1. Dwight M. Jaffee and Kenneth T. Rosen, "Mortgage Credit Availability and Residential Construction," BPEA, 2:1979, p. 374. 
detailed exploration of the mechanism by which monetary policy affected housing during 1980. Table 4 of the paper, for example, makes his point very clearly: the 1980 housing downturn was uniquely affected by high interest rates (operating through the user-cost variable), with an unusually modest role for mortgage-payment and availability effects (the latter measured by thrift institution deposit flows and related variables). I have no problem with this description. But it misses the extreme turbulence in capital markets that leads traditional mortgage lenders to cease making funds available, not because they lacked funds in hand (the traditional availability link), but because they dared not allow those funds out of hand. So again I return to Wojnilower's point in his paper: that 1980 may be a new breed of credit crunch, but it is a credit crunch nonetheless, because that is the mechanism through which monetary policy operates effectively in the end.

In Hendershott's model and econometric results, he first explains the tenure choice decision, that is, whether to become a homeowner; then uses homeownership, a long-run user-cost effect, and a credit-availability variable to determine housing starts; and finally, generates housing quality as a function of income, the user cost of capital, and a mortgage-payment variable. The tenure choice material, following and confirming the work of Harvey and Kenneth Rosen — both singly and jointly—is very useful. Hendershott, wisely I think, uses the adjusted homeownership technique of Jaffee and Kenneth Rosen to clear away those changes in the homeownership rate that arise from shifts in the age distribution and in the propensity of the population to form households. His results then show clearly that a carefully measured user-cost variable is the key determinant of the tenure choice decision. He does not find a significant impact of credit availability on homeownership, whereas Rosen and I did, but that may be a matter of how hard one looks.

A more serious concern, in my view, which relates to all the recent work on tenure choice, is that the homeownership rate has had a steady uptrend over Hendershott's sample, while the user-cost variable has had an equally steady downtrend, raising the possibility of spurious correlation. Looking at the graph of the user-cost variable in figure 1 of the paper, I am worried further because the two key exceptions to this downtrend-before 1960 and between 1979 and 1980 - are not part of the estimation sample. Finally, the accuracy of the quarterly movements of the homeownership rate can be questioned. 
The equation for housing starts is surprisingly simple: the long-run effect of user cost and the change in adjusted homeownership both representing demand, and the availability measure representing the finance constraint. Even if the short-run changes in homeownership were measured accurately, I think there would be some case for additional demand-side variables. Given the imperfections in the data on homeownership, additional variables are needed all the more. A measure of removed units to account for replacement demand is another component missing from the specification of housing starts. Hendershott suggests that the variables specified may account for it in part, but replacement demand is quantitatively too important and too interesting a component of housing production to receive such summary treatment.

The estimated equation for housing starts indicates that an increase of $\$ 1$ billion in thrift institution deposit flows (in 1978 prices) increases starts by 7,000 units at annual rates. The author is highly critical of the Jaffee and Rosen estimate that is more than double this. He fails to recognize, however, that the measure of the availability of thrift institution deposits is a proxy for rationing over the full spectrum of mortgage lending, of which thrift institutions represent, as it turns out, just about one-half.

The third, and last, estimated equation of the model explains the "average quality" of housing starts. Data are again a problem here, but the rich specification, in fact, fits very well.

Finally, I want to comment on the historical, out-of-sample, simulation between 1979:1 and 1980:2. The tracking is poor, with the actual exceeding the predicted by large amounts in all quarters. Even the one observation that is close, housing starts in 1979:1, is wrong because severe winter conditions reduced the actual housing starts by an estimated 300,000 units (according to Jaffee and Rosen). Unfortunately, adjusting the actual number in $1979: 1$ by 300,000 units puts this error right in line with the rest.

The poor tracking is a serious problem. Hendershott suggests two "fixes" for the model in this period, but I view these as unacceptable. The first is to set the availability measure equal to zero for this period, which has the effect of at least distributing the errors positively and negatively. Although availability effects may have been reduced, I see no prior grounds for completely overriding the availability variable in this way.

The second is based on the unusual sharply descending yield curve that existed during the periods that the author takes on the ground for a 
changed response to the high interest rate level. I have no basic problem with the concept; but in the basic equation, the sign goes in the wrong direction for explaining the number of starts. A descending yield curve, indicating expectations of declining interest rates, is a reason to postpone demand. But only if we accept the suppression of the credit-availability variable, thus producing overpredictions in 1980, does this second argument take on the correct sign.

I am afraid that we cannot ignore the obvious, namely that the responsiveness of homeownership to the interest rate has been exaggerated in the estimated equation, thus confirming my fears concerning the spurious correlation between homeownership and the user-cost variable.

I conclude with one general observation on the relation between monetary policy and housing. Even if Hendershott goes too far in eliminating availability effects, one should believe that the recent changes in deposit and mortgage markets may well have significantly reduced the traditional, disintermediation-based, availability link. In discussions leading to these changes over many years, it was noted that monetary policy would have to be tighter to achieve a given effect on aggregate demand if housing were more protected from this mortgage-availability link. The events of the past nine months appear to confirm this strongly. I think this is an improvement from the standpoint of allocational efficiency, but it raises serious questions about stabilization policy. This, of course, is a key point of Wojnilower's paper.

\section{General Discussion}

A number of discussants questioned some aspects of Hendershott's simulations for predicting the effect of changes in inflation, or user costs, on the stock of owned houses. Jeffrey Sachs felt that the simulations were defective because they failed to model the supply side of the housing industry. He pointed out that an explicit supply schedule is required to predict the division of demand increases between price and quantity responses. William Nordhaus noted that, because Hendershott assumed an infinitely elastic supply schedule, his simulations provided upper bounds on the resource reallocation effects of, for example, inflation. Nordhaus noted that Hendershott's simulation of the effects of inflation implied that all observed changes in real interest rates during the simulation period 
had come from inflation. He suggested an alternative simulation in which both inflation rates and interest rates are changed by the same amount from their actual historic values.

Hendershott defended his omission of the supply side on the grounds that he was modeling demand for only a fraction of the output of the construction industry; increases in the demand for residential structures could presumably be satisfied, without substantially increasing costs, by attracting resources from nonresidential construction. He added that during the period of his simulation, nonresidential demand for structures had been particularly weak. William Brainard commented that, because of differences in tax treatment, events such as changes in interest rates or inflation might have opposite effects on the demand for rental and owner-occupied houses. Hendershott's simulations were less likely to overstate the quantity responses when there were such offsetting shifts in demand. Sachs agreed that inflation might discourage investment in rental units because of the adverse tax effects of historical cost depreciation allowances. But he argued that this further demonstrated the need to use a general equilibrium model in which the prices of both rental and owner-occupied houses are endogenous.

Alan Blinder observed that whether the rental price converges to the user cost of capital or vice versa depends on the endogeneity of housing prices and possibly interest rates themselves. The importance of endogeneity, in turn, depends on the time horizon. In the short run, rents might be expected to be relatively stable, with adjustment taking place in the prices of existing houses. In the long run, however, as the stock of housing adjusts, rents would be expected to reach the level implied by the replacement cost of houses. Blinder also felt that the four-quarter moving average that Hendershott had used for computing permanent income was too short.

Benjamin Friedman offered an alternative way of analyzing the interaction between housing construction and prices. He argued that changes in interest rates or inflation that stimulated housing demand would first raise the price of existing houses, and thereby Tobin's $q$ for housing (the ratio of the prices of existing houses to the cost of constructing new houses). As long as $q$ remained above unity, resources would be reallocated to housing construction. Increases in the prices of the natural resource inputs used for home building would increase construction costs and decrease $q$. Barry Bosworth cautioned that the problems in disen- 
tangling land prices from house prices and in comparing old and new houses makes it difficult to estimate $q$. He stressed the importance of distinguishing between the price of housing structures and the price of housing land. If the recent inflation in house values largely reflects increases in land prices, it would not be expected to stimulate investment of resources in housing structures.

The discussion turned to the out-of-sample forecasts of Hendershott's model in which his equations, without adjustment, generally underpredicted both the number of starts and their quality. Some discussants shared Jaffee's uneasiness with suppressing the credit-availability variable to improve the tracking of the numbers of starts and thereby inferring that availability had not been a factor in the latest decline. George Perry noted that this problem arose because of lack of direct evidence on whether mortgages were being rationed. He suggested that the large expansion of mortgage pools during the past cycle-a significant institutional change that integrated the mortgage market more fully into the general capital market-meant total availability was greater than Hendershott's variable based on flows into thrift institutions showed. He observed that when Hendershott reduced the impact of his availability variable, it was equivalent to allowing for greater availability from nonthrift sources. With the credit-availability variable suppressed, as full integration of the mortgage market might require, Hendershott overpredicted starts in the first half of 1980 , the period when mortgage rates peaked and then declined rather than underpredicting them as the equation using the availability variable did; these quarters also showed the largest underprediction of quality per start. Perry suggested that some underprediction of quality might automatically accompany an overprediction of starts because of the changing composition of starts when mortgage markets were tight. Brainard expanded on Hendershott's discussion of the exceptionally inverted yield curve in early 1980 . He noted that estimates of the interest elasticities obtained from a sample period with more normal yield curves would be biased during the forecast period if the yield curve or some proxy was not included in the estimation. One would expect more postponement of starts and less decline in their quality than the biased equation would predict. Whether this consideration supports Hendershott's model thus depends on whether one accepts some suppression of the availability constraint in the forecast period. 